\title{
Lowry モデル族と地域産業連関分析の統合
}

\author{
一一豊田市の都市内部システムへの適用—
}

\section{矢 野 桂 司*}

\begin{abstract}
本稿は，Lowry モデル族が依拠する経済基盤メカニズムの概念的・操作的問題を克服するために，Mac gill (1977) が提唱した地域産業連関分析による一般化 Lowry モデル族を日本最大の自動車生産地域であ る豊田市を対象に適用し，その有効性を検討した。この場合, 研究の最大の焦点となる地域投入係数に関し ては，準調查推定法の1つで比較的精度が高いとされるRAS 法を用いてその推定を行なった。

その結果，経済基盤メカニズムに含まれる基幹部門によってのみ人口および雇用者の水準が決定するとい う算純な仮定や，基幹産業と非基幹産業の定義・分類の問題を明示する一方，経済基盤乗数モデルにかわる 地域産業連関分析による一般化の妥当性を例証した。そしてさらに，基幹部門を内生化させたより包括的な 枠組によるLowry モデル族の定式化の可能性を示唆した。
\end{abstract}

\section{I はじめに}

Lowry モデル族（Lowry，1964）を機軸とした 都市モデル研究は, 都市内部の諸活動の空間的分布 やその間の相互作用を，説明・予測しようとするも のである. Lowry モデルは，外生的に与えられた 基幹産業雇用者数の分布から, 人口や非基幹（サー ビス）産業雇用者数の分布を決定するモデルとして 特徴づけられる. そして，このモデル族は，1) 活 動の発生メカニズムを特定する経済基盤乗数モデル, 2 ) 活動 (人口乞非基幹産業雇用者) の配分メカ二 ズムを特定する 2 つの単一制約型空間的相互作用モ デル，を主なサブ・モデルとして構成されている (矢野, 1986).

1950年代末以降, 北アメリカにおいて大規模な交 通・土地利用計画モデルとして展開された都市モデ ル研究 (Goldner, 1971 ; Lee, 1973) は, 1960年 代末に開発された Wilson（1970）のエントロピー 最大化型空間的相互作用モデルの登場によって急速 に発展した（Batty，1972）。とくに英国における都 市モデル研究では, このWilson のモデルを活動・ 配分のサブ・モデルとして取り入れた Lowry モデ

\footnotetext{
* 東京都立大学・院
}

ル族がその基本となった。そして，このモデル族は， 当時のストラクチャー・プラン ${ }^{1)}$ と密接に関わっ て (Batty, 1978), 理論と実践の両側面からその精 緻化が進められた（戸田，1984a）。そして今日で は, 動態化, 变数の細分化, さらには, 他の地域経 済モデルを連結させた総合的都市モデルの構築を主 要なテーマとして，多くの関連分野においても都市 モデル研究は進展している（Batty, 1981 ; Bertuglia et al. , 1987).

しかしながら，このような都市モデル研究の動向 の中で, 複雑な都市システムのモデル化に関して, 様々な問題点や適用上の限界も明らかにされつつあ る. とくに, Lowry モデル族は, 活動の発生モデ ル上配分モデルを統合した総合モデルであるため, それらサブ・モデルに関する問題が必然的につきま とうことになる，なかでもとりわけ，活動の発生モ デルである経済基盤理論をめぐるいくつかの問題を あげることができる2) (Sayer, 1976 ; Webber, 1984 ; フット, 1984).

都市の経済基盤理論は, 都市の産業を, 基幹産業 （域外への販売を目的とした商品やサービスの生産 を行なう産業）と非基幹産業（域内での販売を目的 とした商品やサービスの生産を行なう産業）の 2 組 
の生産活動に分離し，基幹産業によって新たにもた らされた所得がその産業自体を発展させ, 非基幹産 業に対しても成長基盤を与え，その結果，当該地域 の産業が発展する亡仮定するものである，Lowry モデルでは，両産業を雇用者数で指標化し，基幹 産業の雇用者数を入力として, 人口一雇用比率 Inverse activity rate と, サービス雇用一人口比率 Population-serving ratio を用いることにより， 人口および非基幹産業雇用者数を推定する。しか し，こうした因果メカニズムの単純さに対する批判 (Sayer, 1976, pp. 195 201) に加え, 両産業の正 確な定義・分類の困難さ（Massey，1973）など, 多くの問題がある．このような短所があるにもかか わらず, 経済基盤乗数モデルは, 操作性が優れ, デー夕の入手が比較的簡単なことから，これまでの 都市モデル研究において, 顕著な改良を加えられる ことなしにその適用がなされてきた。

こうした状況を克服するために，Macgill (1977) は, 経済基盤乗数モデルにかわり, 地域産業連関分 析（投入一産出モデル）をLowry モデル族に取り 込むことで, 両モデルの一般化を試みた。この一般 化の最大の利点は, 従来の Lowry モデルにおいて 全く無視されてきた産業部門間の相互作用を考慮す るところにある。しかし，この試みに関しては，モ デル式が特定されているものの, 未だその実証研究 はみられない，その最大の障害の 1 つは，投入一産 出モデルにおける投入係数（技術係数之も呼ばれ る）の推定である. Leontief の産業連関分析の有 効性は周知の如くであるが ${ }^{31}$, 産業連関表の作成に は膨大な費用之時間を必要とする。このことは，国 家スケールでの産業連関分析だけでなく, 地域ス ケールないし都市スケールでの地域産業連関分析に おいても同様である。こうした問題に対し，地域経 済学者を中心とする地域産業連関分析研究では, 国 家スケールでの投入係数を援用して, 対象地域の投 入係数を推定する様々な方法（非調查推定法や一部
調査デー夕を用いる準調查推定法) が開発されてき た(Morrison and Smith, 1977 ; Hewing, 1985).

以上の研究動向をふまえ, 本稿は, 日本最大の自 動車生産地域である豊田市を対象にして, Macgill （1977）が提唱する地域産業連関分析による一般化 Lowry モデル族を適用し，その有効性を検討する ことを目的とする. その際, 研究の最大の焦点とな る投入係数に関しては, 準調査推定法の 1 つで比較 的精度が高いとされる RAS 法4) を用いて推定を行 なうことにする.

本稿の分析手順は次のとおりである. まず第章 において, 経済基盤乗数メカニズムの問題点を整理 し, Lowry モデルの基本構造と比較しながら, 一 般化 Lowry モデル族のモデル構造を提示する。こ のモデル族は, 地域内産業連関表に対応する集計的 空間レベルと, 地域間産業連関表に対応する非集計 的空間レベルそれぞれにおいて定式化される5 。 。 して第且章において, 愛知県の投入係数に RAS 法 を適用し, 豊田市の投入係数を推定した後, その係 数を用いて, 第IV章では, 一般化 Lowry モデル族 の豊田市への適用を試みることにする。

\section{Lowry モデル族と地域産業連関分析の統合}

1) 経済基盤乗数メカニズムとその問題点

経済基盤乗数メカニズムには, 次の 2 つの仮定が 含意されている ${ }^{6)}$ １）基幹産業雇用者数と人口お よび非基幹産業雇用者数の間に固定された比率が存 在する，2）都市の総活動量は基本的に，当該都市 からの移出の水準によって決定される. これらの仮 定は, 必然的に, 都市の成長をもたらす他の影響の 存在を認めないばかりか, 完全に需要側のモデル であり，労働力などの供給側を全く無視している (Sayer, 1976, pp. 195 201 ; フット, 1984, pp. 101 102, 123). また, Webber (1984, pp. 106〜 113）は，基幹産業の立地は外生的に与えられ，人 ロはその立地にしたがうという Lowry モデルの仮 
定は,アメリカの都市ではあてはまらず, 両者はむ しろ相互依存的であり, それらの分布には他の多く の要因が影響を与えていることを例証している.

さらにこうしたモデルの非現実的な仮定の問題 に加え, 操作上の問題として, 基幹産業と非基幹産 業の定義・分類の問題がある (Webber, 1984, pp. 94〜96).これまでの代表的な Lowry モデル族の 実証研究では，様々な基準のもとで分類が行なわれ てきた。

例えば Lowry（1964）は，基幹産業を，域外へ の財やサービスの生産にたずさわり，立地的には居 住人口乞独立なものと定義し, 非基幹産業を, 域内 の人口に財やサービスを提供するもので, 人口に対 して市場指向的な産業と定義している. それに対し Batty（1976, p. 86）は, 基幹産業を, その立地が 局地的経済に対して外生的な移出指向的産業である と定義している。また Foot et al. (1978，p. 17) は, 基幹産業を, その空間的分布が人口の分布と独 立した産業と定義し, 人口との相関係数が 0.85 未 満の産業を基幹産業とみなしている。さらにEchenique et $a l$. (1969, p. 284) は, 基幹産業を, 域 外へ移出する製品や財を生産し, その立地が局地的 な市場に対する近接性之無関係であるという必要条 件を満たす産業と定義している。このような混然と した状況を整理するために，Massey（1973）は， 而産業の理論的な定義として，生産的基準，立地的 基準，機能的基準の 3 つを設定し ${ }^{7) ， L o w r y(1964) ~}$ の分類が立地的基準と機能的基準の 2 つの基準を混 合して用いるため, 彼の分類は曖昧なものとなって いることを指摘している。しかし，英国での奏証研 究では，デー夕の制約から標準産業分類 Standard Industrial Classificationをもとに両産業が分類 されているのが実情である。すなわち, 産業分類番 号 1１6 をもつ産業が基幹産業に，分類番号 17 24 をもつ産業が非基幹産業に分類されているのである.
2）地域産業連関分析による Lowry モデルの一 般化

前記の経済基盤理論をめぐる諸問題を克服するた めに, Macgill (1977) は, 経済基盤乗数モデルに かわり, 地域産業連関分析の枠組を取り入れ, Lowry モデルの一般化を追究した ${ }^{8)}$. この一般化 は, 経済基盤乗数モデルが投入一産出モデルの特別 な場合であることが指摘されている事実 (Romanoff, 1974）や, Lowry モデル族の行列表示が開 発されていること（Garin, 1966 ; Broadbent, 1973), さらに, Lowry モデル族と他の都市モデル (人口学的モデルなど) との統合が試みられている こと (Schinnar, 1978 ; Gordon and Ledent, 1980）などを考慮するならば，順当な試みであった といえる. 以下では, Macgill (1977) が提唱した, 地域産業連関分析を用いた Lowry モデルの一般化 の枠組にしたがい，1）地区間と部門間の相互作用 の側面からみた Lowry モデル族の基本構造の要約, 2）地域内産業連関表に対応する集計的空間レベル での一般化，3）地域間産業連関表に対応する非集 計的空間レベルでの一般化, を順次提示することに する ${ }^{9}$.

1. Lowry モデル族の基本構造

反復計算を基調とするLowry モデルの基本構造 は, 矢野 (1986, pp. 525 528) に示されているの で，ここでは後述の一般化との比較のために，亡く に空間的相互作用と部門間の相互作用に焦点をおい て説明を行なうことにする。

まず，第 1 回目の繰り返し段階において，基幹産 業雇用者数の空間的分布 $E_{j}^{B}$ が外生的に与えられる. そして, それに伴って発生する通勤流 $T_{i j}$ は, 次の 吸収制約型空間的相互作用モデルによって推定され る.

$$
\begin{aligned}
& T_{i j}=B_{j} W_{i} E_{j} f^{H}\left(c_{i j}\right), \\
& B_{j}=1 / \sum_{i} W_{i} f^{H}\left(c_{i j}\right),
\end{aligned}
$$


（ただし， $W_{i}$ は地区 $i$ の居住立地魅力， $E_{j}$ は地区 $j$ の雇用者数, $f^{H}\left(c_{i j}\right)$ は距離関数である.なお, 第 1 回目の繰り返しにおいては $E_{j}=E_{j}^{B}$ である.) この結果から, 地区 $i$ に居住する雇用者 $\sum_{j} T_{i j}$ に関 連する人口 $P_{i}$ は, 雇用一人口比率 $\alpha$ を用いて, 次 のように確定される.

$$
P_{i}=\alpha \sum_{j} T_{i j}
$$

次に，推定された地区 $i$ の人口 $P_{i}$ による非基幹 部門 $R k \sim の$ 消費支出額 $S_{i j}^{R k}$ は, 非基幹部門 $R k$ に 対する人口 1 人当たりの消費支出額を $e^{R k}$ とすれば, $e^{R k} P_{i}$ で計算され, 以下の発生制約型空間的相互作 用モデルによって，各地区の非基幹部門 $R k$ に配分 される.

$$
\begin{aligned}
& S_{i j}^{R k}=A_{i} e^{R k} P_{i} W_{j}^{R k} f^{R k}\left(c_{i j}\right), \\
& A_{i}=1 / \sum_{j} W_{j}^{R k} f^{R k}\left(c_{i j}\right),
\end{aligned}
$$

（ただし， $W_{j}^{R k}$ は地区 $j$ の非基幹部門 $R k$ のサービ 立地魅力, $f^{R k}\left(c_{i j}\right)$ は距離関数である。)

この結果から, 地区 $j$ の非基幹部門 $R k$ の雇用者数 $E_{j}^{R k}$ は, 地区 $j$ での総消費支出額 $\sum_{i} S_{i j}$ を, $R k$ 部 門の雇用者 1 人当たりの生産額 $h^{R k}$ で除することに よって推定される.

$$
E_{j}^{R k}=\sum_{i} S_{i j} / h^{R k}
$$

この非基幹部門 $R k$ の雇用者数 $E_{j}^{R k}$ は，次の反復計
算の新たな入力データとして用いられる.すなわち， 前揭の（1），(2）式より，非基幹部門 $R k$ に対する 通勤流が推定され，次いで（3）式を用いて，この 雇用者に関連した居住人口の増加を各地区ごとに算 出する。.さらに，この居住人口分布から非基幹部門 $R k$ への消費支出額が推定され, 再度 (4), (5) 式 を用いて，非基幹部門の消費支出額の増加分が各地 区へ配分される，そしてそれによって，各地区の新 たな非基幹部門の雇用者数が推定され，この増加分 が第 3 番目の反復計算の入力として使用される.こ の反復計算は, 新たな人口および非基幹産業雇用者 数の増加がほとんどみられなくなるまで続けられる. 最終的に，地区 $i$ の人口数 $P_{i}$ と地区 $j$ の非基幹産 業雇用者数 $E_{j}^{R k}$ は，それぞれ次式のように推定さ れることになる.

$$
\begin{aligned}
& P_{i}=\sum_{n} P_{i}, \\
& E_{j}^{R k}=\sum_{n} E_{j}^{R k},
\end{aligned}
$$

\section{（ただし， $n$ は反復回数である.）}

\section{2. 集計的空間レベルでの一般化}

Macgill（1977）による集計的空間レベルでの Lowry モデルの一般化は，Lowry モデル族の特定 式を，当該地域全体を 1 つのシステムとしてみなし た地域内産業連関表にあてはめることから，容易に 理解される.第 1 図は集計的空間レベルでの Lowry モデルの産業連関表的表現である。行方向および列

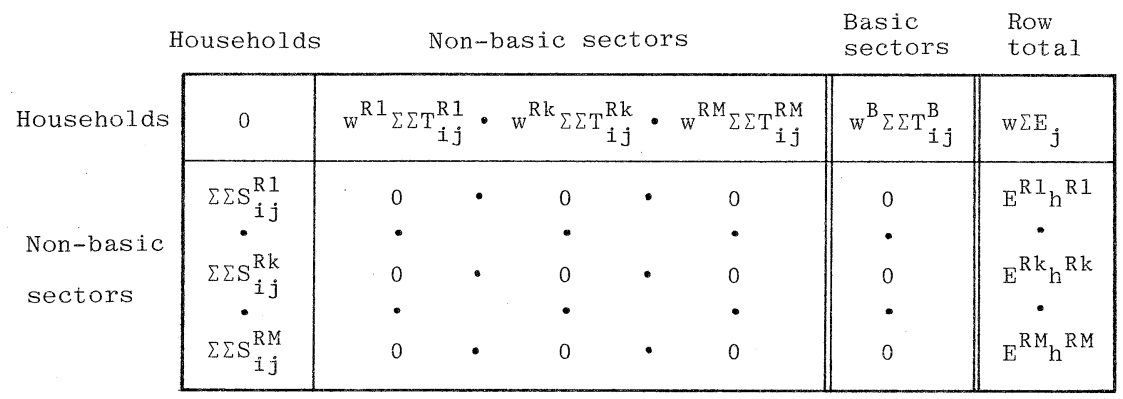

第 1 図地域内産業連関表による集計的空間レベルでの Lowry モデルの一般化

Fig. 1 Spatially-aggregated Lowry model as an intra-regional input-output model

(After Macgill (1977)). 
方向は，Lowry モデルと同様に，世帯（居住）部 門，基幹部門，非基幹部門から構成されている(こ の分類は Lowry モデルとの比較のためであり, 実 際は，いかなる部門が配置されていてもかまわな い). 通常の投入一産出モデルと異なるのは次の 2 点である. 1) 投入一産出モデルでは外生的に扱わ れる最終需要の列が基幹部門となっている，2）通 常は最終需要に計上される家計部門（家計消費支 出）が内生的に組み込まれた，いわゆる，家計内生 化（あるいは消費内生化）型の投入一産出モデルで ある。この地域内産業連関表は, 通常のもの之同様 に, 列方向の費用構成はある部門がその生産物を作 るための生産要素を投入した構成を示し，行方向の 販路構成は生産物の配分構成を示すものである。そ の単位は, 列部門に対して, 行部門が産出する費用 である. 以下の説明で用いられる変数は基本的に前 節のものに準じるが, 変数の添え字は, Hが世帯,

$B$ が基幹産業， $R k$ が非基幹部門の $k$ 産業を示して いる.

まず第 1 に，世帯部門の行は，世帯部門から非基 幹部門ならびに基幹部門への労働の産出を示すもの で, 非基幹部門 $R /$ への産出は $w^{R k} \sum_{j} E_{j}^{R k}$, 基幹部 門への産出は $w^{B} \sum_{j} E_{j}^{B}$ で表わされる。ただし， $w^{R k}$, $w^{B}$ は，それぞれ非基幹部門 $R k$ および基幹部門の 雇用者 1 人当たりの賃金である。これらはまた， (1)，(2）式を用いることによって,

$$
\begin{aligned}
& w^{R k} \sum_{j} E_{j}^{R k}=w^{R k} \sum_{i} \sum_{j} T_{i j}^{R k}, \\
& w^{B} \sum_{j} E_{j}^{B}=w^{B} \sum_{i} \sum_{j} T_{i j}^{B},
\end{aligned}
$$

と表わすことも可能である。ここでは，世帯部門は 他の世帯部門へ労働を産出することはなく, 労働を 他の地域へ移出することもない, と仮定している. その結果, 前者の事項に該当するセルには 0 が割り 当てられる.

次に, 非基幹部門の行は非基幹部門 $R k$ からの産 出を示しているが, Lowry モデル・メカニズムに
したがえば，世帯部門以外への産出は０である. （4）（5）式を, 非基幹部門 $R k$ から世帯部門への 産出の流動と考えるならば,

$$
\begin{aligned}
& S_{i j}^{R k}=A_{j} e^{R k} P_{j} W_{i}^{R k} f^{R k}\left(c_{i j}\right), \\
& A_{j}=1 / \sum_{i} W_{i}^{R k} f^{R k}\left(c_{i j}\right),
\end{aligned}
$$

(これらの式は，(4)，（5）式の $i, j$ が逆転したもの である.)

によって推定される，地区 $i$ の非基幹部門 $R k$ から 地区 $j$ の世帯部門への産出の総計 $\sum_{i} \sum_{j} S_{i j}^{R k}$ が, 当該 セルに割り当てられる.

そして，投入係数を推定するのに必要な各行部門 からの総生産は以下のように計算される。世帯部門 の総生産, すなわち, 世帯部門からの総労働力は次 のように算出される。

$$
\begin{aligned}
& \sum_{k} w^{R k} \sum_{i} \sum_{j} T_{i j}^{R k}+w^{B} \sum_{i} \sum_{j} T_{i j}^{B} \\
& =w E,
\end{aligned}
$$

(ただし，Wは雇用者 1 人当たりの平均賃金, $E$ は 総雇用者数である.)

また, 非基幹部門 $R k$ の総産出は, 非基幹部門 $R k$

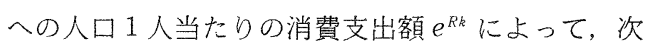
のように算出される.

$$
\sum_{i} \sum_{j} S_{i j}^{R k}=e^{R k} P=h^{R k} \sum_{j} E_{j}^{R k}
$$

(ただし， $P$ は総人口， $h^{R k}$ は非基幹部門 $R k$ の雇 用者 1 人当たりの産出額である.)

以上の部門間の相互作用が，Lowry モデル・メ カニズムによって考慮されてきたものである、した がって, そこでは世帯部門からの労働力は全て域内 の非基幹部門之基幹部門に配分され，非基幹部門か らの産出は全て域内の世帯部門八消費されるものと 仮定されている.

ここで，投入一産出モデルにおいて重要な役割を 果たす $n$ 部門が，生産 1 単位当たり必要とする $m$ 部 門からの投入単位（投入係数 $r^{m n}$ ) は以下のように 計算される。

$$
r^{H H}=0,
$$




$$
\begin{aligned}
r^{H R k} & =w^{R k} \sum_{i} \sum_{j} T_{i j}^{R k} / h^{R k} \sum_{j} E_{j}^{R k} \\
& =w^{R k} / h^{R k} \\
r^{R k H} & =\sum_{i} \sum_{j} S_{i j}^{R k} / w E=e^{R k} P / w E, \\
r^{R k R k} & =0 .
\end{aligned}
$$

$r^{H R k}$ は非基幹部門 $R k$ の産出 1 単位当たりの $R k$ 部 門への労働力を示し, 逆に, $r^{R k H}$ は世帯部門の労働 1 単位当たりの, 非基幹部門 $R k$ から世帯への消費 支出額を示している. 非基幹部門 $R k$ の総生産額を $X^{R k}$, 非基幹部門の総数を $M$ とすると, それらは前 掲の投入係数を用いて, 次のように表わされる.

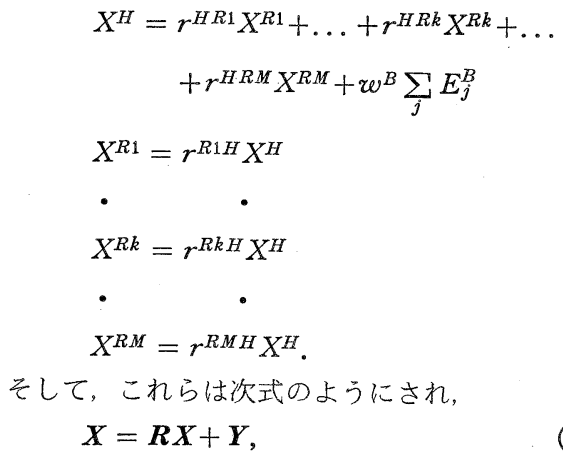

そして，これらは次式のようにされ，

$$
\boldsymbol{X}=\boldsymbol{R} \boldsymbol{X}+\boldsymbol{Y},
$$

通常の投入一産出モデル同様に次のようになる.

$$
\underline{\underline{X}=(\boldsymbol{I}-\boldsymbol{R})^{-1} \boldsymbol{Y}}
$$

（ただし，Iは単位行列である.)

また，この場合，投入係数行列 $R$ は既知であり，そ れらの係数は次のように固定された值である.

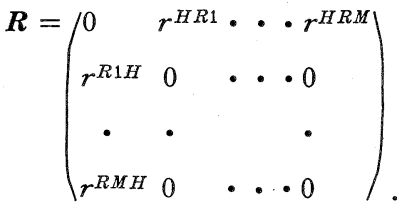

$Y$ は外生部門ベクトルであるが，この場合，世帯部 門から基幹部門への労衝力の産出以外は 0 である。

$$
\boldsymbol{Y}=\left(\begin{array}{c}
w^{B} \sum_{j} E_{j}^{B} \\
0 \\
\cdot \\
0
\end{array}\right)
$$

次式で表わされる $\boldsymbol{X}$ は総生産額ベクトルで，(21)式 によって推定されるものである.

$$
\boldsymbol{X}=\left(\begin{array}{c}
X^{H} \\
X^{R 1} \\
\cdot \\
X^{R M}
\end{array}\right) .
$$

このように（21）式を解くことによって，集計 的空間レベルにおけるLowry モデルの一般化が達 成されることになる。また，総雇用者数 $E$ は世帯部 門の総生産額 $X^{H}$ を雇用者 1 人当たりの平均賃金 $w$ で除することから推定され，人口Pはそれに人口一 雇用比率 $\alpha$ を乗することから算出される.

$$
\begin{aligned}
& E=X^{H} / w, \\
& P=\alpha E .
\end{aligned}
$$

また, 非基幹部門 $R k$ の総雇用者数 $E^{R k}$ は，非基幹 部門 $R k$ の総生産額 $X^{R k}$ を，それに従事する雇用 者 1 人当たりの生産額 $h^{R k}$ で除することによって,

$$
E^{R k}=X^{R k} / h^{R k},
$$

と推定される.

3. 非集計的空間レベルでの一般化

対象地域が $I$ 個の地区にゾーン分割された場合の 地域産業連関分析によるLowry モデルの一般化は, 第 2 図の地域間産業連関表を対応させることによっ て表わすことができる。この一般化の枠組において は，各部門の発地区之着地区が識別され，各部門， 各地区ごとの総生産額が推定されることになる。ま た，第 2 図の地域間産業連関表の各セル $Z_{i j}^{m n}$ は，地 区 $i$ の部門 $m$ から地区 $j$ の部門 $n$ への産出が示され ている，第 2 図では説明のため，2つの非基幹部門， 3つの地区から構成されている場合を示した.

まず，基幹産業雇用者の空間的分布 $E_{j}^{B}$ が外生的 に与えられているとすると, 各地区の世帯部門から 基幹産業への産出は，(1)，(2)，(10）式を用いて,

$$
\begin{aligned}
& w^{B} \sum_{j} T_{i j}^{B}=w^{B} \sum_{j} B_{j} W_{i} E^{B} f^{H}\left(c_{i j}\right), \\
& B_{j}=1 / \sum_{i} W_{i} f^{H}\left(c_{i j}\right),
\end{aligned}
$$




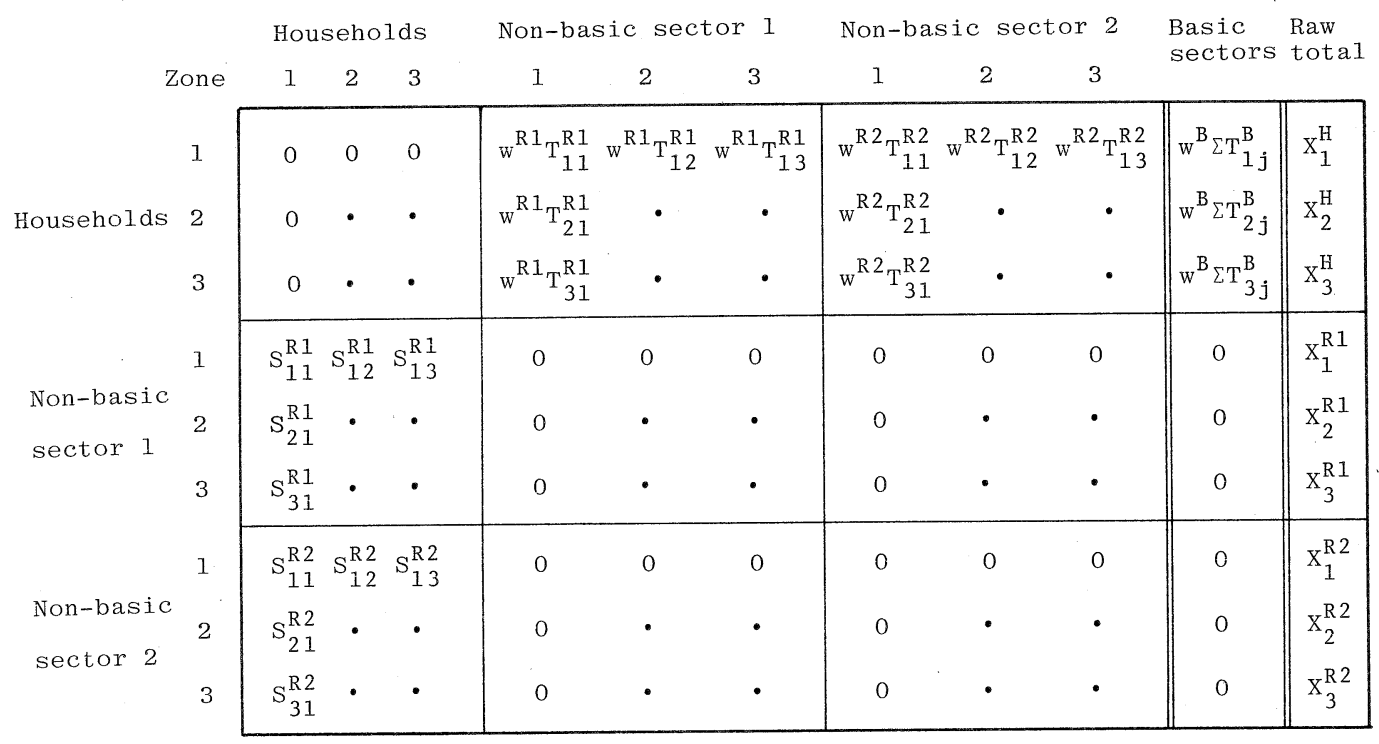

第 2 困地域間産業連関表による非集計的空間レベルでの Lowry モデルの一般化

Fig. 2 Spatially disaggregated Lowry model as an inter-regional input-output model

(After Macgill (1977)).

と特定され，第 2 図の世帯部門の行之基幹部門の列 が交差するセルに記入される，基幹部門の列の残り は 0 である.

この世帯部門からの産出 (労衝力) は, 世帯部門 の所得の増加をひきおこし，非基幹部門から世帯部 門への産出を生じさせる。この地区 $i$ の非基幹部門 $R k$ から, 地区 $j$ の世帯部門への産出額 $S_{i j}^{R k}$ は, (11), （12）式によって特定され，第 2 図の非基幹部門の 行と世帯部門の列が交差するセルに記入される.

さらに, 非基幹部門における生産は, その生産に 必要な非基幹産業雇用者数の増加をひきおこす。そ して, この増加は世帯部門から非基幹部門 $R k$ への 労働の産出として，(1)，(2)，(9) 式を用いて,

$$
\begin{aligned}
& w^{R k} T_{i j}^{R k}=w^{R k} B_{j} W_{i} E_{j}^{R k} f^{H}\left(c_{i j}\right) \\
& B_{j}=1 / \sum_{i} W_{i} f^{H}\left(c_{i j}\right)_{\circ}
\end{aligned}
$$

と特定される.この産出は, 世帯部門の行と非基幹 部門 $R k$ の列が交差するセルに記入される.なお， 特定されなかったセル（世帯部門間, 非基幹部門間 の相互作用）には 0 が割り当てられる.
このように，雇用者 1 人当たりの賃金や産出額を 介して特定された部門間，そして地区間の相互作用 を第 2 図のような地域間産業連関表に対応させるこ とによって, Lowry モデルは非集計的空間レベル においても，地域産業連関分析の特殊ケースとして 包揁されることになる．ここで，外生部門として扱 われた世帯部門から基幹部門への労働の産出を入力 データとして，総生産額を推定するためには, 式の（地域内）投入係数に対応する地域間投入係数 が与えられなければならない。しかし，この地域間 投入係数は，地域内のものよりもさらにデー夕の収 集が困難となる.この問題に対して, 地域内投入係 数に重力モデルを適用することから地域間投入係数 の推定が試みられている (Webber, 1984, pp. 102 $\sim 104$ ).

まず，世帯部門から非基幹部門への労働の産出に 関する地域間投入係数 $r_{i j}^{H R k}$ は，(1)，(2)，(16)式 を用いて次のように推定される.

$$
\begin{aligned}
r_{i j}^{H R k} & =w^{R k} T_{i j}^{R k} / h^{R k} E_{j}^{R k} \\
& =r^{H R k} B_{j} W_{i} f^{H}\left(c_{i j}\right) .
\end{aligned}
$$


次に，非基幹部門から世帯部門への産出（世帯部 門から非基幹部門への消費支出額）に関する地域間 投入係数 $r_{i j}^{R k H}$ は，(11)，(12)，(17）式を用いて次 のように推定される。

$$
\begin{aligned}
r_{i j}^{R k H} & =S_{i j}^{R k} / w E_{j} \\
& =r^{R k H} A_{j} W_{i}^{R k} f^{R k}\left(c_{i j}\right) .
\end{aligned}
$$

また, 残りの世帯部門間之非基幹部門間の地域間投 入係数は, Lowry モデル・メカニズムにおいては 無視されているために，0が割り当てられる.

$$
\begin{aligned}
& r_{i j}^{H H}=0, \\
& r_{i j}^{R k R k}=0 .
\end{aligned}
$$

このようにして Lowry モデルとしてみた地域間 投入係数は，(16)，(17）式によって推定される地 域内投入係数から導出することが可能となるのであ 万.

そして (19)式と同様に, 各地区 $(1,2, \cdots, i, \cdots I)$, 各部門 $(1,2, \cdots, m, \cdots M)$ ごよの総生産額 $X_{i}^{m}$ は,

$$
\begin{aligned}
X_{1}^{H}= & r_{11}^{H R 1} X_{1}^{R 1}+r_{12}^{H R 1} X_{2}^{R 1}+\ldots \\
& +w^{B} \sum_{j} T_{1 j}^{B} \\
X_{I}^{H}= & r_{I 1}^{H R 1} X_{1}^{R 1}+r_{I 2}^{H R 1} X_{2}^{R 1}+\ldots \\
& +w^{B} \sum_{j} T_{I j}^{B} \\
X_{1}^{R 1}= & r_{11}^{R 1 H} X_{1}^{H}+\ldots+r_{1 I}^{R 1 H} X_{I}^{H} \\
\bullet & \\
X_{I}^{R M}= & r_{I 1}^{R M H} X_{1}^{H}+\ldots+r_{I I}^{R M H} X_{I}^{H},
\end{aligned}
$$

であることから, (21)式と同様に，

$$
\underline{\underline{X}=(\boldsymbol{I}-\boldsymbol{R})^{-1} \boldsymbol{Y}}
$$

と推定されることになる。

ただし， $R$ は次のように表わされる地域投入係数行 列である。

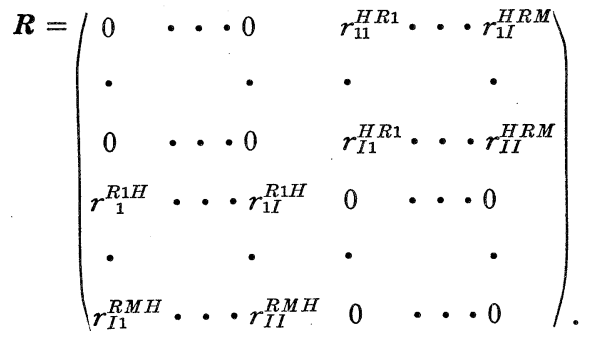

$Y$ は次のように表わされる外生部門ベクトルである。

$$
\boldsymbol{Y}=\left(\begin{array}{c}
w^{B} \sum_{j} T_{1 j}^{B} \\
\cdot \\
w^{B} \sum_{j} T_{I j}^{B} \\
0 \\
\bullet \\
0
\end{array}\right) .
$$

また， $X$ は次のように表わされる総生産額ベクトル である。

$$
X=\left(\begin{array}{l}
X_{1}^{H} \\
X_{I}^{H} \\
X_{1}^{R 1} \\
\bullet \\
X_{I}^{R M}
\end{array}\right) .
$$

さらに, Lowry モデル・メカニズムとの対応を 考えた場合，各地区の人口および非基幹部門 $R k$ の 雇用者数の水準, 地区間の通勤流亡買物流の分布が 推定されなければならない，それらは，最終的に推 定された総生産額を用いて以下のように算出される. まず地区 $i$ の口 $P_{i}$ は，次式のように推定される.

$$
P_{i}=\alpha X_{i}^{H} / w,
$$

（ただし， $\alpha$ は人口一雇用比率， $X_{i}^{H}$ は地区 $i$ の居 住部門の総産出額, $w$ は雇用者 1 人当たりの平均賃 金である。)

次いで, 地区 $i$ の非基幹部門 $R k$ の雇用者数 $E_{i}^{R k}$ は,

$$
E_{i}^{R k}=X_{i}^{R k} / h,
$$

（ただし， $X_{i}^{R k}$ は地区 $i$ の非基幹部門 $R k$ の総算出 額, $h^{R k}$ は非基幹部門 $R k$ の雇用者 1 人当たりの生 産額である.)

他方，地区 $i$ の世帯部門から地区 $j$ の部門 $m$ への 通勤流 $T_{i j}^{m}$ は, (32)式より, 次のように推定される.

$$
T_{i j}^{m}=r_{i j}^{H m} X_{i}^{m} / w^{m},
$$

(ただし， $r_{i j}^{H m}$ は世帯部門から $m$ 部門への労働の産 出に関する地域間投入係数, $X_{i}^{m}$ は地区 $i の m$ 部門 の総産出額, $w^{m}$ は $m$ 部門に従事する雇用者 1 人当 


\section{たりの賃金である。）}

買物流に関しては, (11), (12) 式によって算出さ れる地区 $j$ の世帯部門から地区 $i$ の非基幹部門 $R k$ への消費支出額 $S_{i j}^{R k}$ を人 1 人当たりの消費支出額 $e^{R k}$ で除することによって, 次のように推定するこ とができる。

$$
S_{i j}^{R k}\left|e^{R k}=r_{i j}^{R k} X_{i}^{H}\right| e^{R k} .
$$

本章では, Lowryモデル・メカニズムの地域産 業連関分析による一般化を, 地域内投入一産出モデ ルに対応する集計的空間レベルと, 地域間投入一産 出モデルに対応する非集計的空間レベルで行なった. 両レベルでの産業連関表（またそれに対応する投入 係数行列) にみられる多くの0の存在は, Lowry モデル・メカニズムが扱う地区間, 部間間の相互作 用が，極めて限られたものであること示唆している。 しかし，データの入手可能性を不問とするならば， 非基幹部門間の相互作用は，該当する投入係数を用 いることによって，容易に取り入れることができる. さらに, 基幹部門を外生部門とみなす従来の Lowry モデル・メカニズムにかわり，基幹部門を内生化す ることから，他の指標（最終需要など）を外生部門 とする一般化を試みることも可能である.これに よって, Lowry モデル・メカニズムでは完全に無 視されていた，基幹部門之世帯部門，さらには非基 幹部門といった全部門間の相互作用が考慮されるこ とになる。 その結果，基幹部門と非基幹部門の区別 は問題とならず，必然的に両者の定義・分類をめぐ る議論も回避されることになる。

\section{III 豊田市の地域産業連関}

1）地域投入係数の推定方法

産業連関分析を地域スケールで適用する場合の最 大の障害は，地域産業連関表を作成するのに必要な データの収集の問題である，とくに，投入一産出モ デルを実行する際に必要な地域内（間）投入係数の 特定には，膨大な費用と時間が費やされることにな
る(Round, 1983)，それゆえ，地域経済学者らは実 質的なフィールド調查や高価な作成費用を省くため に，国家スケールの投入係数を基礎として，地域投 入係数を推定する非調査推定法や，一部の地域デー 夕を用いて，国家スケールの投入係数を修正して推 定する準調查推定法を開発してきた（Morrison and Smith, 1977, pp. 122 128; Hewing, 1985, pp. $46 \sim 57$ ).

非調査推定法として最も簡便な方法は, その出発 点として，国家スケールでの投入係数で地域投入係 数を近似させる方法である。これは，当該地域に関 する情報が皆無に等しい場合に限り容認されるもの の, 空間的スケールによる資本ストックの世代変化 の違いや，プロダクト・ミックスや技術構造の差異 が全く無視されることから，極めて非現実的なもの であるといえる(Hewing，1985，p．47)。これに 対して, 全国スケールおよび当該地域での各部門ご との雇用者数（ないしは総生産額）などの単純な統 計資料から算出される立地係数によって, 国家ス ケールの投入係数を重み付ける立地係数法が開発さ れている (Schaffer and Chu, 1969).

この結果, 非調査・準調査推定法によって推定さ さた投入係数や乗数の精度が論議を呼び（Round， 1983)，異なった推定方法による結果の比較 (Schaffer and Chu, 1969 ; McMenamin and Haring, 1974 ; Morrison and Smith, 1974), ならびに, 実際の調查によってえられた係数との比較（Czamanski and Malizia, 1969; Hewing, 1971 ; Malizia and Bond, 1974) が行なわれるように なった，目下のところ, 対象地域のいくつかの地域 データによって国家スケールの投入係数を修正する 準調査推定法の 1 つである RAS 法の有効性が確認 されている(Morrison and Smith, 1974, 1977, pp. $127 \sim 128$ ).

RAS 法は, 本来, 国家スケールの投入係数の時 系列的予測に対して開発されたものであるが（Ba- 
charach, 1970), Czamanski and Malizia(1969) はそ扎を地域投入係数の推定に適用した。 RAS 法 によって必要とされる地域デー夕は, 当該地域の中 間産出額ベクトル $\boldsymbol{u}(R)$, 中間投入額ベクトル $\boldsymbol{v}$ $(R)$, 総生産額ベクトル $\boldsymbol{X}(R)$ である.そして, これらのデータを制約条件として, 反復計算によっ て, 国家スケールの投入係数行列 $\boldsymbol{A}(N)$ を調整す る方法が RAS 法であるといえる，その適用手順は 以下の上うである。

まず，投入係数行列 $\boldsymbol{A}_{0}$ を国家スケールの投入係 数行列 $\boldsymbol{A}(N)$ として, 当該地域の総生産額ベクト ル $\boldsymbol{X}(R)$ から, 中間産出額ベクトル $\boldsymbol{u}_{1}$ を推定する.

$$
\boldsymbol{u}_{1}=\boldsymbol{A}_{0} \boldsymbol{X}(R) \text {. }
$$

この推定された $u_{1}$ と実際の中間産出額ベクトル $u$ $(R)$ の比率によって, 調整された投入係数行列 $A_{1}$ が導かれる。

$$
\boldsymbol{A}_{1}=\hat{\boldsymbol{u}}^{(R)} \hat{\boldsymbol{u}}_{1}^{-1} \boldsymbol{A}(N),
$$

（ただし，一は対角行列を意味する。）

次に, この投入係数行列 $A_{1}$ 之当該地域の総産出額 ベクトルから中間投入額ベクトル $v_{1}$ を推定し,

$$
\boldsymbol{v}_{1}=\hat{\boldsymbol{X}}(R) \boldsymbol{A}_{1}^{\prime} \boldsymbol{i},
$$

(ただし， $i$ は単位ベクトルである.) それと実際の中間投入ベクトル $v(R)$ との比率か ら投入係数行列 $A_{1}$ を調整し，新たな投入係数行列 $A_{2}$ を推定する。

$$
A_{2}=\boldsymbol{A}_{1} \hat{\boldsymbol{v}}(R) \hat{\boldsymbol{v}}_{1}^{-1} .
$$

そして， $\boldsymbol{A}_{0}=\boldsymbol{A}_{2}$ として，(45）式に戻り, 投入係 数行列が収束するまで反復計算が行なわれる.した がって，このようにして推定された地域投入係数は， 地域データの制約のもとで最も国家スケールの投入 係数に近似したものであるといえる。

2) 豊田市の地域投入係数

研究対象地域としては, 筆者の先の研究 (矢野, 1986 ; Yano, 1987) によってその都市の内部構造 が明らかになりつつある, 日本最大の自動車生産地 域である豊田市が選ばれた（第 3 図）。産業部門の
分類としては，日本産業分類の大分類にしたがうも のの，デー夕の制約上，世帯部門，基幹部門（農林 水産業, 鉱業, 製造業, 建設業), 非基幹部門（電 気・ガス・水道業, 卸売・小売業, 金融・保険・不 動産業, 運輸・通信業, サービス業) の 3 部門, 9 産業の名義的な分類を採用した。また，ゾーン分割 に関しては，流動現象に関するデー夕を必要とする ことから，1981年のパーソン・トリップ調査（以下, $P T$ 調査と呼ぶ）によるゾーン分割を基本的に踏襲 した。しかし，豊田市を47に分割する最小単位地区 に基づいた場合，活動の水準が 0 になる地区が多く みられ，単位地区を 1 つの経済単位とみなすには不 適切である。それゆえ，それら最小単位地区を統合 したBゾーンに相当する，20地区からなるゾーン分 割を採用した。

豊田市はトヨ夕自動車の本拠地のあるわが国最大 の自動車製造地域であり，その人口は 283,245 人で, 総雇用者数の約 $55 \%$ に当たる 80,520 人が製造業に 従事している(1981年現在)。豊田市の経済はこの 強固な基幹産業に支えられ，その発展に伴って卸売 ・小売業やサービス業をはじめとする非基幹産業も 発達してきた。これら産業間, さらに地区間の関係 は直接的・間接的な波及効果を通して互いに影響を 与えあっており, それらの連結を要約し，表にまと めたものが地域産業連関表であるといえる.

しかし, 豊田市の地域産業連関表は作成されてい ないため，前節で提示した非調査ないし準調査推定 法を援用して，豊田市の地域投入係数を推定しなけ ればならない，その場合，基礎となる適切な国家ス ケールでの投入係数が必要であるが，ここでは 1980 年度の愛知県の地域産業連関表を利用することが可 能である（愛知県企画部，1985），RAS 法を用い ての豊田市の地域投入係数の推定に際しては, 愛知 県の地域投入係数以外に, 豊田市での各部門, 各産 業ごとの総生産額, 中間投入額, 中間産出額, と いった地域デー夕が必要である。しかし，それらに 


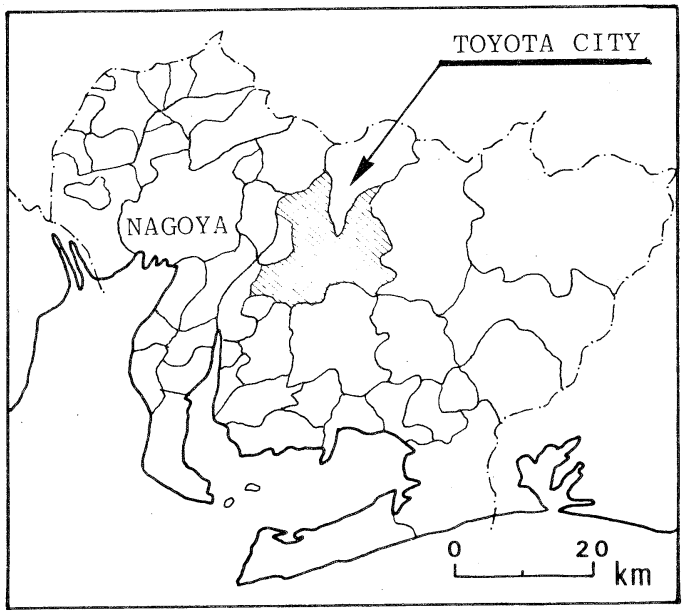

( AICHI PREFECTURE)

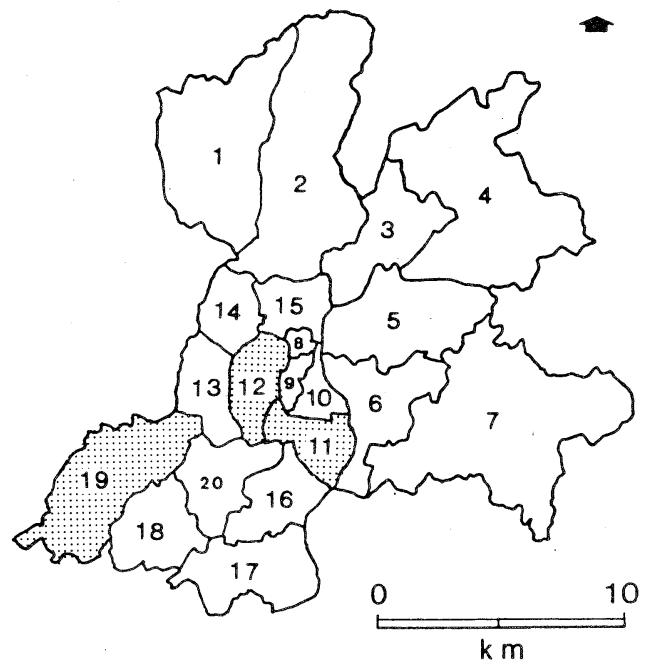

Area where the main factories are located

\section{第 3 図対 象 地 域}

Fig. 3 Study area

1. Homi 2. Shanage 3. Koshido 4. Ishino 5. Takahashi-kita 6. Takahashi-minami 7. Matsudaira 8 Toyotashi-eki 9. Uwagoromo 10. Chyokoji 11. Toyota and Yamanote 12. Koto, Shin and Koromogahara 13. Tsuchihashi and Honji 14. Miyaguchi 15. Umetsubo 16. Kamigo-kita 17. Kamigo-minami 18. Wakabayashi 19. Komaba and Tsutsumi 20. Obayashi

関連するデータの収集がほとんご困難であることか ら, 以下のように, 愛知県の地域産業連関表に全面 的に依存することにする.

まず，コントロール・トータルスと呼ばれる各部 門ごとの総生産額は, 愛知県の従業者 1 人当たりの 生産額に豊田市の当該部門の雇用者数を乗じること から推計した。次に，中間投入額としては，豊田市 の各部門ごとの純生産から雇用者所得を差し引いた 額を付加価値とし, 先に推計した総生産額からこの 付加価値を差し引くことによって推計した。. そして 中間産出額としては, 中間投入額の小計を愛知県の 中間産出額の各部門ごとの比率で配分した。また, 最終需要は総生産額から中間産出額を差し引くこと によって推計した。なお，投入係数の推定に用いた 豊田市の地域デー夕は『豊田市の統計』（豊田市, 1984）によっており, 以下の分析に用いられる投入 係数以外のデー夕も基本的にこの資料によっている.
このように推計された豊田市の総生産額, 中間投 入額, 中間産出額に基づいて, 愛知県の地域投入係 数をRAS 法によって修正した。 そして，(45）式 から（48）式の反復計算を行なったところ， 7 回の 繰り返しの後に投入係数はほぼ収束した．次章では， この推定された豊田市の地域内投入係数を基礎とし て，一般化 Lowry モデルを実証することにする。

\section{IV 一般化 Lowry モデルによる豊田市の 都市内部システムの分析}

本章では RAS 法によって推定された豊田市の地 域内投入係数に基づいて, Lowry モデルの地域産 業連関分析による一般化を行なうことにする。集計 的空間レベルと非集計的空間レベルに分け，各々に ついて，まず第 1 に基幹部門を外生部門とし，贸 基幹部門間の相互作用が存在しないものとする, Lowry モデルの仮定に忠実なモデルの実行（モデ 
ルa）を行なう．次に，非基幹部門間の相互作用を 取り入れた一般化（モデルb）を行なう。そしてさ らに, 基幹部門を内生化させ, 最終需要を外生部門 とした，より一般的な枠組によるモデルの実行（モ デルc）を，順に行なうことにする。これらモデル の概要を図示すると第 4 図のようになる。

1）集計的空間レベルでの一般化

地域内投入一産出モデルに対応する集計的空間レ ベルでの Lowry モデルの一般化は，豊田市全体を 1 つの地域とみなすものであり，地区間の相互作用
が集計される結果，部門間の相互作用のみが問題上 なる。集計的空間レベルでは，総人口および各部門 ごとの総雇用者数から計算される総生産額が既知で あり，それに基づいて投入係数が推定されている。

したがって, 当然, 推定された最終需要を外生部門 として（21）式を実行すると（モデル c に対応す る), 各部門ごとの活動の水準は観察値と全く一致 することになる，そこで，集計的空間レベルの場合 はモデル $\mathrm{c}$ を除き，地域内投入係数に基づいて，モ デル $a, b$ を実行することにする.

MODEL 2-a,b

MODEL $1-a, b$

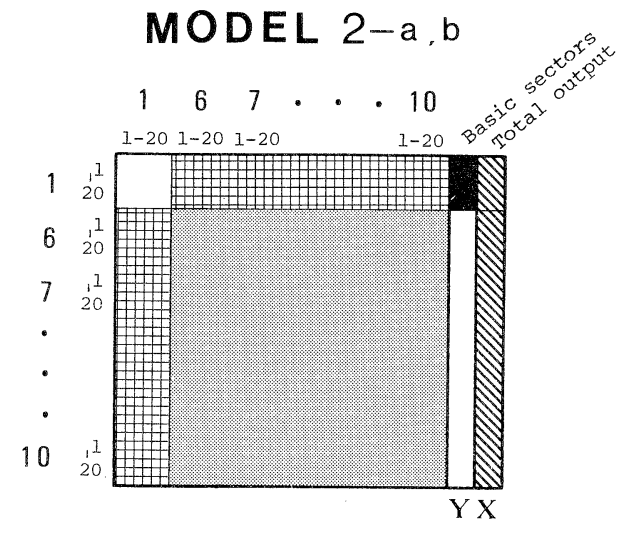

MODEL 2-c

2-5: Basic sectors

6-10: Non-basic sectors

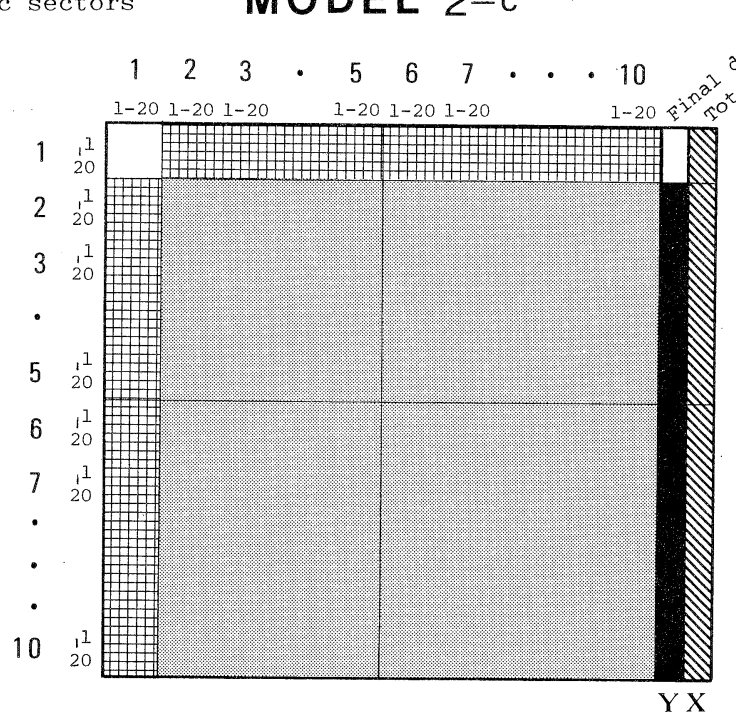

第 4 図適用モデルの概要

Fig. 4 Outline of input-output Lowry models in this paper 
1. モデル $1-\mathrm{a}$

モデル 1-a は, 従来の Lowry モデル・メカニズ ムと同様に，世帯部門から基幹部門への労働力の産 出を外生部門とし, 非基幹部門間の相互作用が全く 存在しないと仮定するものである（第 4 図参照）。 それゆえ，世帯部門と 5 つの非基幹産業の $6 \times 6$ か らなる地域内投入係数行列が用いられるが，世帯部 門間および非基幹部門間の投入係数は 0 が割り当て られている. 入力データとしては，外生部門ベクト ルが (23) 式の形で世帯部門から基幹部門への産出 （労㗢力）として与えられる。また，外生部門べク トルの残りの非基幹部門から基幹部門への産出には 0 が割り当てられている。このような地域内投入係 数行列と外生部門ベクトルから（21）式を実行した 結果を，第 1 表にまとめた，推定される活動水準は， 人口之 5 つの非基幹産業の各雇用者数である，人口 や金融・保険・不動産業, サービス業は観察値に近 い值が推定されているが，全体的に過小評価されて おり, とくに運輸・通信業, 卸売・小売業, 電気・ ガス・水道業の雇用者数の推定値は観察值の50\%に も満たない。これらの結果から，Lowryモデル・ メカニズムは, 実際に存在する産業部門間の相互作 用のうち、ごく限られたものだけを扱っているこ上 が示唆される。

2. モデル $1-b$

次に, RAS 法によって推定された非基幹産業部 門間の投入係数を用いることによって，非基幹部門
間の相互作用を取り入れ (第 4 図参照), Lowry モ デルの仮定をゆるめたモデルの実行を行なった（第 1 表). 結果は，全般的には非基幹部門間の相互作 用を無視したモデル 1-a の結果に比べ，実際の活 動水準に近い值を示している。しかし, 卸売・小売 業と運輸 - 通信業の雇用者数は, 依然, 過小評価さ れている。このことは, RAS 法によって推定され た両非基幹産業の製造業に対する投入係数が，他の 非基幹産業に比べ $2 \sim 3$ 倍の高い値を示しているこ とから（製造業に対する卸売・小売業の投入係数は 0.06569 , 運輸・通信業は 0.03646 である)，両非基 幹産業と基幹部門の産業，とくに，製造業との相互 作用が無視しえないことを示唆しているものといえ る。それゆえ，基幹部門を外生部門とする Lowry モデル・メカニズムの限界は歴然としており，基幹 部門を内生化させ, 非基幹部門之基幹部門の間の相 互作用を考慮した，より一般的なモデル・メカニズ ムの開発が必要であるといえよう。なお，金融・保 険・不動産業の雇用者の推定値には，30\%近い過大 評価がみられる。

2) 非集計的空間レベルでの一般化

非集計的空間レベルでの Lowry モデルの一般化

は，各部門間の相互作用を豊田市の20単位地区ごと に取り入れた地域間投入一産出モデルに対応するも のである，まず，(37）式を実行する前に，(38) 式 で表わされる各部門をさらに地区ごとに細分した地 域間投入係数を推定しなけ机ばならない，地区 $i の$

第 1 表＼cjkstart集計的空間レベルでの Lowry モデルの一般化の実行結果

Table 1 Results of spatially aggregated input-output Lowry model(model 1-a, b)

\begin{tabular}{l|r|r|r|r|r}
\hline \multirow{2}{*}{ Sector } & \multirow{2}{*}{ Obs. } & \multicolumn{2}{|c|}{ Model 1-a } & \multicolumn{3}{c}{ Model 1-b } \\
\cline { 4 - 6 } & & Pred. & $\%$ & Pred. & $\%$ \\
\hline Households(population) & 283425 & 254981 & 90.0 & 273365 & 96.5 \\
Non-basic sectors(employment) & & & & & \\
Electricity, gas and water & 340 & 167 & 49.1 & 325 & 95.6 \\
Commerce & 24903 & 11785 & 47.3 & 16551 & 66.5 \\
Finance, insurance and real estate & 3120 & 2962 & 94.9 & 4047 & 129.7 \\
Transportation and communication & 5679 & 2031 & 35.8 & 4210 & 74.1 \\
Service & 15392 & 13109 & 85.2 & 15630 & 101.5 \\
\hline
\end{tabular}


世帯部門から地区 $j$ の非基幹部門 $R k$ への産出に関 する地域間投入係数は（32）式を用いて推定され， 地区 $i$ の非基幹部門 $R k$ から地区 $j$ の世帯部門への 産出に関する地域間投入係数は（33）式を用いて推 定される. そして, Lowry モデル・メカニズムで は無視されてきた世帯部門に関連しない残りの, 地 区 $i$ の部門 $m$ から地区 $j$ の部門 $n$ への産出に関する 地域間投入係数は, 吸収制約型の重力モデルによっ て次のように推定される.

$$
\begin{aligned}
& r_{i j}^{m n}=r^{m n} C_{j} W_{i}^{n} f^{m}\left(c_{i j}\right) . \\
& C_{j}=1 / \sum_{i} W_{i}^{n} f^{m}\left(c_{i j}\right) .
\end{aligned}
$$

ここでモデルの実行に際し，適切な立地魅力指標 $W_{i}^{n}$ と距離関数 $f^{m}\left(c_{i j}\right)$ を特定しなければならない。 立地魅力指標己しては, デー夕の制約から, 立地魅 力に最委関連すると考えられる, 各発地区の当該部 門の活動水準を採用した。すなおち, 居住部門から の投入係数の推定に際しては各地区の人口を, 基幹 部門方よび非基幹部門からの投入係数の推定に際し ては各地区の当該産業の雇用者数を，それぞれ用い た. 他方, 距離関数に関しては, 先の研究（矢野, 1986）と同様，都市内スケールの分析において適切 よされる次のような指数関数を用いることにする.

$$
f\left(c_{i j}\right)=\exp \left(\lambda c_{i j}\right),
$$

(ただし， $c_{i j}$ は $P T$ 調査からえられた地区 $i, j$ 間の 時間距離，入は距離パラメータである.)

距離パラメータの推定に際しては, 当該流動の平
均時間距離に基づいてキャリブレーションが行なわ れるべきであるため(Batty and Mackie, 1972)， 世帯部門から基幹部門方よび非基幹部門への投入係 数推定に関連する距離パラメータは, 各業種ごとの $P T$ 調査からえられた通勤流の平均時間距離に基づ いて推定された（第 2 表）。しか，各部門から世 帯部門への投入係数や，世帯部門以外の部門間の投 入係数の推定に関連する距離パラメータの推定に関 しては, 利用可能なデータがほとんど存在しない. それゆえ，前者に関しては，PT 調査の買物流から えられた平均移動距離によってキャリブレーション された距離パラメータ值 $(-0.37450)$ を全部門に 対して用いることにする，後者に関しては，関連す る情報が全く存在しないため，距離の影響が全くみ られない場合 $(\lambda=0.0)$ から, 強い距離の抵抗を仮 定する場合 $(\lambda=-0.4)$ まで, 0.05 刻みに距離パラ メー夕を設定し，9通りの地域間投入係数行列(200 ×200）を作成した，以下では，これらの係数に基 づいて，非集計的空間レベルでの地域産業連関分析 によるLowry モデルの一般化を，モデル a, b , c の順に行なうことにする。

1. モデル $2-\mathrm{a}$

ここでは，世帯部門から非基幹部門への，そして 非基幹部門から世帯部門への相互作用のみを考慮し た，Lowry モデル・メカニズムの仮定に最も忠実 な非集計的空間レベルでのモデルの実行が行なわれ

第 2 表 居住立地モデルに関連する距離パラメー夕

Table 2 Distance-decay parameters for residential location model

\begin{tabular}{l|c}
\hline \multicolumn{1}{c|}{ Sector } & Distance parameter for journey-to-work \\
\hline Agriculture, forestry and fishery & -0.17499 \\
Mining & -0.19605 \\
Manufacturing & -0.10802 \\
Construction & -0.12724 \\
Electricity, gas and water & -0.09624 \\
Commerce & -0.14938 \\
Finance, insurance and real estate & -0.09178 \\
Transportation and communication & -0.09320 \\
Service & -0.14879 \\
\hline
\end{tabular}


る(第 4 図参照).すなわち，先に推定した地域間 投入係数のうち，世帯部門と非基幹部門の間の係数 のみが用いられ，残りのセルには 0 が割り当てられ た（38）式の形の $120 \times 120$ の地域間投入係数行列 (6 部門 $\times 20$ 地区) と，(39) 式の形で与えられる世 帯部門から各地区の基幹部門への労働力の産出のみ からなる外生部門ベクトルを入力として，(37）式 を実行した．各地区の人口ならびに非基幹部門の各 雇用者数の推定值とその適合度は, 第 3 表に要約し た. また，人口，卸売・小売業の雇用者の観察値お よび推定值の空間的分布は第 5 図に示した。各地区
の値を用いて計算された相関係数がさし示すように， 人口以外の非基幹産業雇用者数の適合度は高いもの の, 各部門ごとの雇用者総数は集計的空間レベルで のモデル 1-a の結果と同様，全体的に過小評価さ れている。モデル適合状況を空間的にみてみると, 人口に関しては，豊田自動車の主要工場が立地する トヨタ・山之手 [11]，コト・新・衣ケ原〔12]，駒 場・堤〔19〕に過度の過大評価がみられ, 北部や東 部の周辺地区に過小評価がみられる，また，卸売・ 小壳業の推定値に関しては全体的に過小評価されて いるが, 中心部の商業集積地区をはじめ, 北部や東

第 3 表＼cjkstart非集計的空間レベルでの Lowry モデルの一般化の実行結果

Table 3 Results of spatially disaggregated input-output Lowry model(model 2-a, b)

\begin{tabular}{l|r|r|r|r|r}
\hline \multirow{2}{*}{ Sector } & \multirow{2}{*}{ Obs. } & \multicolumn{2}{|c|}{ Model 2- $\mathrm{r}$} & \multicolumn{3}{c}{ Model 2-b } \\
\cline { 3 - 6 } & & Pred. & $\mathrm{r}$ & Pred. & $\mathrm{r}$ \\
\hline Households(population) & 283425 & 253128 & 0.4955 & 271379 & 0.5093 \\
Non-basic sectors(employment) & & & & & \\
Electricity, gas and water & 340 & 167 & 0.6386 & 325 & 0.7574 \\
Commerce & 24903 & 11785 & 0.8009 & 16551 & 0.8806 \\
Finance, insurance and real estate & 3120 & 2962 & 0.7091 & 4047 & 0.8361 \\
Transportation and communication & 5679 & 2031 & 0.8820 & 4210 & 0.9302 \\
Service & 15392 & 13109 & 0.7634 & 15630 & 0.7933 \\
\hline
\end{tabular}

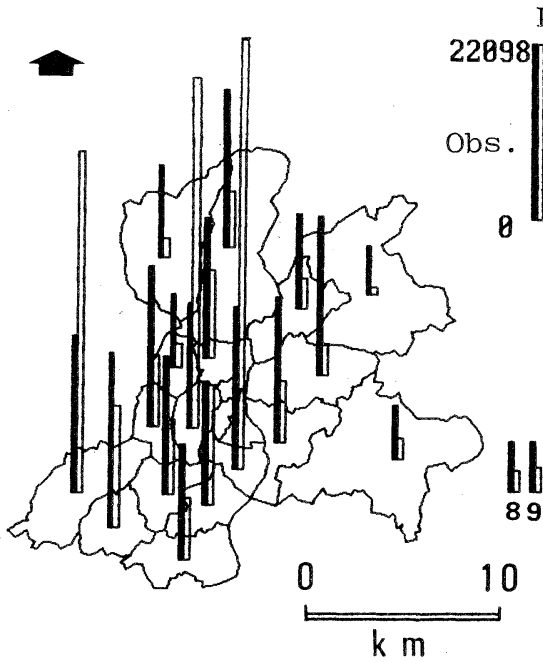

a) Population

10
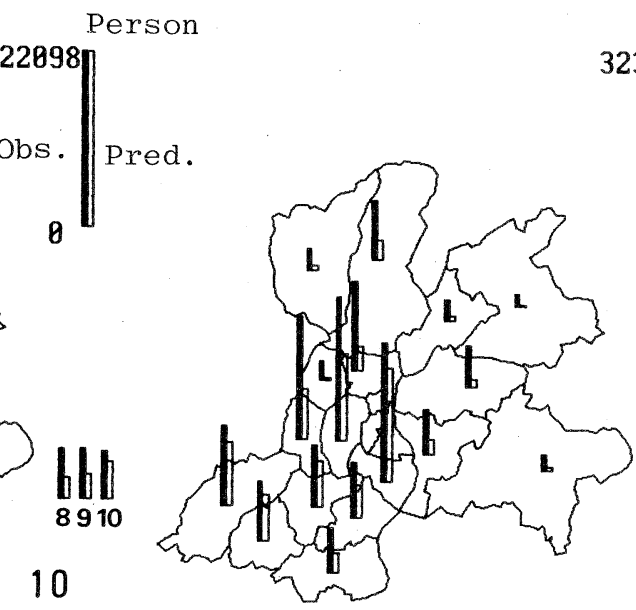

(

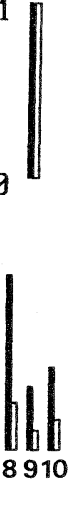

b) Commerce employment

第 5 図 モデル 2-a の適用結果 (人口, 卸売・小売業雇用者数)

Fig. 5 Distributions of population and commerce employment predicted by model 2-a 
部の周辺地域に過度の過小評価がみら机る。また， 同様のことは他の非基幹産業にもいえるが，運輸・ 通信業では南部地区での過小評価，サービス業では 人口の分布同様, 工場立地地区での過大評価, 北部 や東部の周辺地区での過小評価が特徴的である（図 省略).

また，流動現象に関しては，(43)，（44）式に よって，非基幹部門への通勤流および世帯部門から 非基幹部門への買物流が推定される，推定された人 口の分布が工場立地地区にかたよっているため，全 体的に適合度は良くない，例えば，卸売・小売業へ の買物流をみてみると, 観察された流動パターンは, 域内最大の商業集積地である豊田市駅 [8]，大規模 スーパーの立地するトヨタ・山之手 [11]，コト・ 新・衣ケ原〔12]ををその主要着地区とするが，推定 された流動パターンは工場立地地区を中心とした南 部地域に密である(第 6 図).

2. モデル $2-\mathrm{b}$

次に，モデル 2-a に各地区ごとの非基幹部門間 の相互作用を加え，Lowry モデル・メカニズムの 仮定をゆるめたモデルの実行を行なった（第 3 表）.

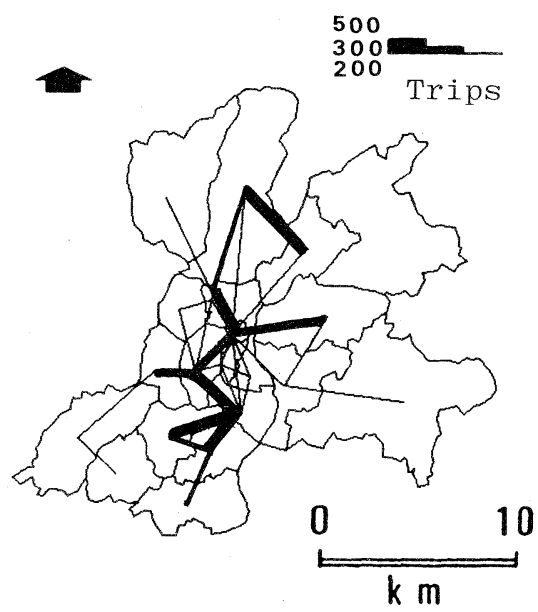

a) Observed
この場合, 非基幹産業部門間の距離パラメー夕を特 定しなければならないが, 前述のようにデータが全 く存在しないため, 試行錯誤的にパラメー夕を設定 し, それぞれの実行結果を比較した。 その結果, 全 体的には距離の影響が強くなるほよ゙適合度は低下す るが，極端な相違はみられなかった。そこで，ここ では距離パラメータをー0.1 とした場合の実行結果 を考察する.

モデル 2-a の結果に比べ, この場合, 推定され た総活動水準は観察された值に近づくと同時に，相 関係数による適合度が相対的に上昇している。こう した傾向は集計的空間レベルの結果と同様である. 推定された人口の空間的分布は, モデル 2-a の結 果よほぼ同様に, 工場の立地する地区での過度の過 大評価, 北部や東部の周辺地区での過小評価がみら れる(図省略)。しかし，推定された非基幹産業の 雇用者の空間的分布は，モデル 2-aに比べ，概ね 良好な適合度を示している(図省略)。より詳細に みてみると, 卸売・小売業に関しては, 域内最大の 商業集積地である豊田市駅 [8] での推定値の過小 評価がみられ, サービス業に関しては, 大学の立地

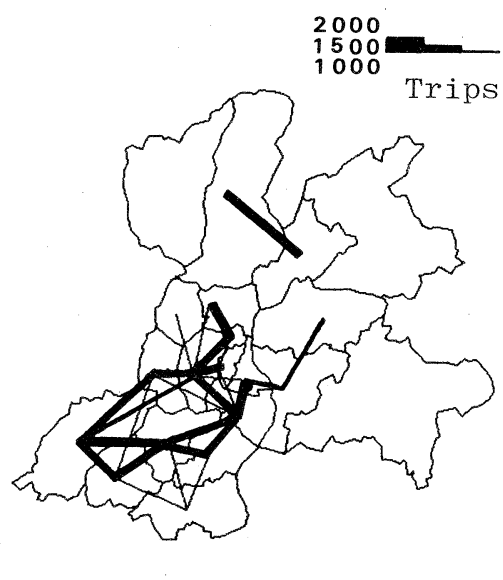

b) Predicted

第6図モデル2-a の適用結果（買物流）

Fig. 6 Flow patterns of journey-to-shop predicted by model 2-a 
する保見〔1〕をはじめとして, 北部や東部の周辺 地区での推定值の過小評価がみられる。 また, 運 輸・通信業に関しては, 豊田自動車関連の大規模 モーター・プールが立地する上郷南〔17〕之駒場・ 堤〔19〕での過小評価がみられる。これら工場立地 地区周辺部における相対的な過大評価の傾向や特定 の施設が結果に及ぼす影響などは, ゾーン分割が異 なるものの，従来の Lowry モデル族の適用によっ てえられた結果（矢野，1986）においても観察され たものである。また，流動現象に関しては，推定さ れた通勤流，買物流ともに，モデル 2-a に比べ流 動量は増加するが，それらの流動パターンはいずれ

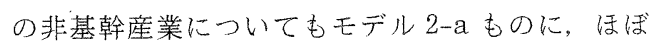
一致している.

以上の結果から，非集計的空間レベルにおいても， 非基幹部門間の相互作用は無視しえないものである といえよう.

\section{3. モデル $2-c$}

最後に, 最終需要を外生部門として与え, 基幹部 門を内生化させた一般化 Lowry モデルの適用を試 みることにする。したがってこの一般化では， Lowry モデル・メカニズムにおいて全く無視され てきた，居住部門間の相互作用を除く他のすべての 部間間，そして地区間の相互作用が考慮されること
になる，地域間投入係数行列としては，先に推定さ れたモデル 2-b と同様に, 居住部門以外の部門間 に関する距離パラメー夕を -0.10 とした $200 \times 200$ の投入係数行列を用い(第 4 図参照), 入力デー夕 に相当する各部門, 各地区ごとの最終需要には, 先 に推計された部門ごとの最終需要を各地区の当該産 業の雇用者数で比例配分したものを割り当てた。な お，世帯部門の最終需要は各地区とも0である。こ れらをも之に（37）式を実行した結果は第 4 表にま とめた。

推定された総人口は若干過小評価されているもの の，投入係数が計算上各部門ごとの総生産額を観察 值と等しくなるように推定されているため, 各産業 ごとの総雇用者数の推定值は観察値と一致している。 人口の推定値は, 先のモデル 2-a, b に比べ相関係 数による適合度が上昇しており, その空間的分布に 関しても工場立地地区にみられた極端な過大評価は みられず，北部や東部の周辺地区での過小評価を除 け代，概衩良好な適合度を示している（第 7 図-a）。 さらに，推定された各産業の雇用者数をみてみると， 絶対量が少なく雇用者数 0 の地区が多く存在する農 林水産業, 鉱業, 電気・ガス・水道業を除けば, 相 関係数による適合度は良好である。とくに，主要な 基幹産業である製造業や建設業の空間的分布は，極

第 4 表 基幹部門を内生化させた一般化 Lowry モデルの実行結果

Table 4 Results of generalized input-output model(model 2-c)

\begin{tabular}{l|r|r|r} 
& \multirow{2}{*}{ Sector } & Obs. & \multicolumn{2}{|c}{ Model 2-c } \\
\cline { 3 - 4 } & & Pred. & \multicolumn{1}{c}{$\mathrm{r}$} \\
\hline Households(population) & 283425 & 281371 & 0.7527 \\
Basic sectors(employment) & & & \\
Agriculture, forestry and fishery & 163 & 163 & 0.0357 \\
Mining & 218 & 218 & -0.3486 \\
Manufacturing & 80520 & 80520 & 0.9957 \\
Construction & 8757 & 8757 & 0.9962 \\
Non-basic sectors(employment) & & & \\
Electricity, gas and water & 340 & 340 & 0.3019 \\
Commerce & 24903 & 24903 & 0.9087 \\
Finance, insurance and real estate & 3120 & 3120 & 0.6979 \\
Transportation and communication & 5679 & 5679 & 0.8248 \\
Service & 15392 & 15392 & 0.7588 \\
\hline
\end{tabular}




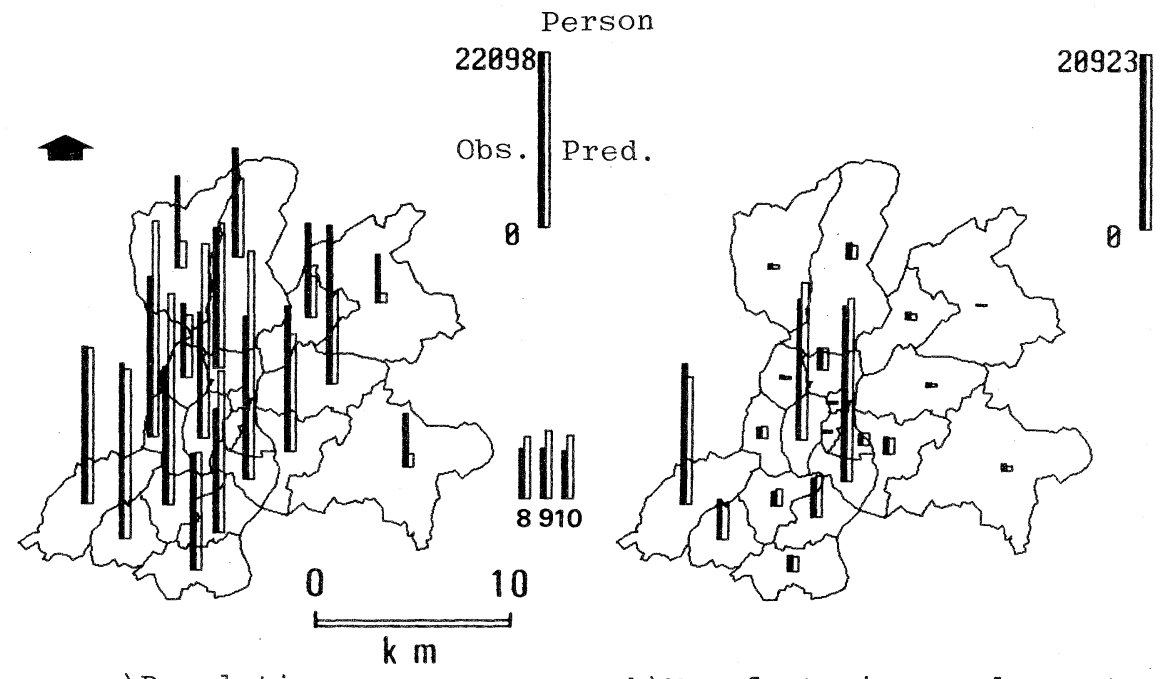

a) Population

b) Manufacturing employment

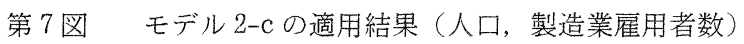

Fig. 7 Distributions of population and manufacturing employment predicted by model-c

めて良好な適合度がみられる(第 7 図-b). 電気・ ガス・水道業, 金融・保険・不動産業, 運輸・通信 業, サービス業では, 相関係数による適合度はモデ ル2-bに比べ若干低下しているが, 卸売・小売業 では適合度は上昇している。それらの産業の残差の 空間的分布をみてみると, モデル 2-b の結果と同

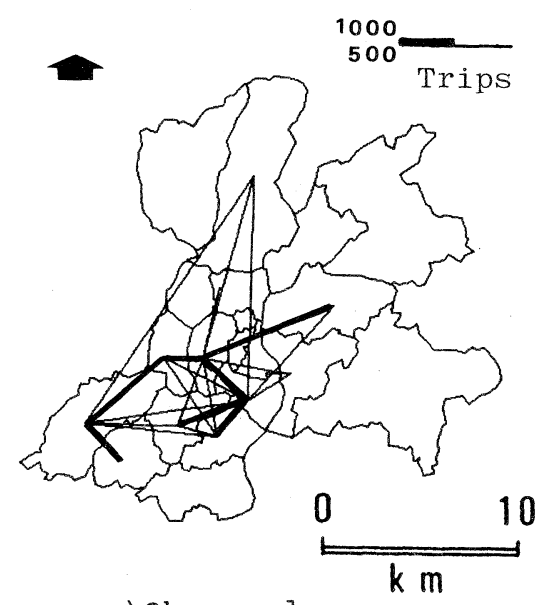

a) Observed
様に, 卸売・小売業では豊田市駅 [8] での推定値 の過小評価, サービス業では保見〔1〕をはじめと して, 北部や東部の周辺地区での推定値の過小評価 がみられる.さらに, 運輸・通信業では, 上鄉南 [17〕之駒場・堤〔19〕での過小評価がみられる(図 省略).

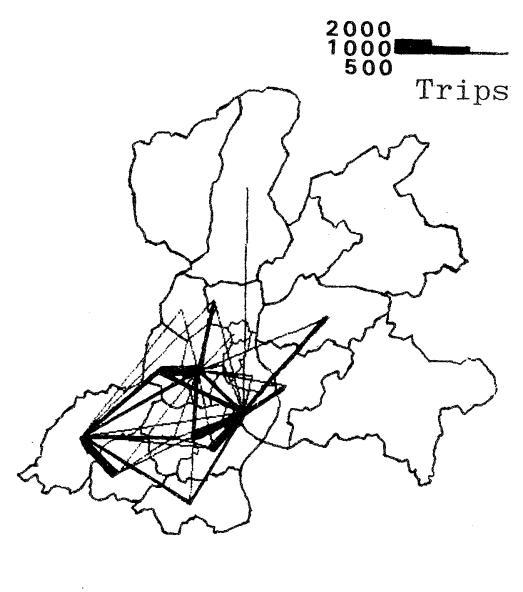

b) Predicted

第 8 図 モデル 2-cの適用結果(通勤流(製造業))

Fig. 8 Flow patterns of journey-to-work of manufacturing predicted by model 2-c 
次に流動現象に関しては, すべての産業ごとに通 勤流および買物流の流動パターンが推定されるが, ここでは誌数の都合上, 豊田市の重要な基幹産業で ある製造業に関する通勤流と，PT調查からえられ る実際の流動パターンとの比較が可能な，世帯部門 から卸売・小売業への買物流を取り上げることにす る。観察される製造業の通勤流動パターンは, 豊田 自動車の主要工場が立地する南部のトヨタ・山之手 [11]，コト・新・衣ケ原〔12]，駒場・堤 [19]を 主要着地区とするパターンがみられるが，モデルは ほぼそれに類似したパターンを推定している（第 8 図)。しかし，流動量の絶対数は，雇用者がすべて 域内に居住するという仮定によって過大評価されて いる，また，豊田自動車の本社工場の立地するトヨ 夕・山之手 [11]八の通勤流をみてみると, 観察值 と推定值はほぼ類似したパターンを示すが, 推定さ れた通勤流は南部地域からのものが多少過大評価さ れている(第 9 図)。他方, 買物流に関しては, モ デルの結果が世帯部門からの総消費支出額から推定 されているため単純な比較はできないが, 推定され た流動パターンにおいては，モデル 2-a，b 上同様

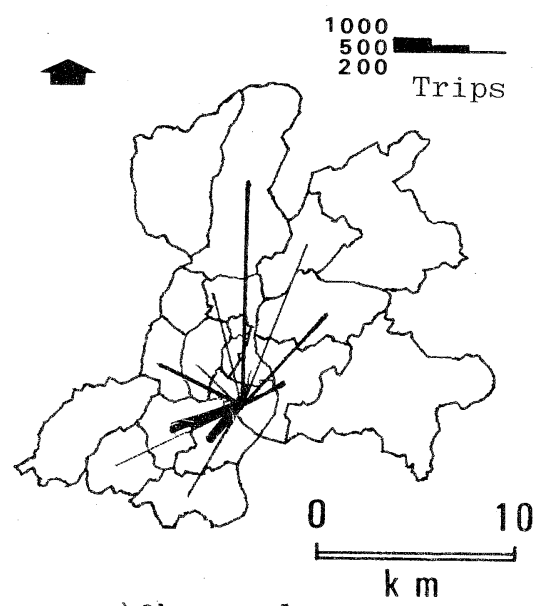

a) Observed
に豊田市 [8] への買物流が相対的に過小評価され， 南部地域での流動が過大評価されている(図省略).

以上の様に基幹部門を内生化させ, 全部門・全地 区間の相互作用を取り入れることから, Lowryモ デル・メカニズムの一般化を試みた結果, 従来の仮 定に即したモデルに比べ, より適切な結果をえるこ よができた。この結果を評価する際, データの制約 上, 多くの仮定（例えば，地域間投入係数の推定に 用いられた距離パラメータ（值が一定）が設けられて いることを考慮する必要があるが, 提示されたモデ ルぶ Lowry モデル・メカニズムの枠組を離れたよ り包括的なモデルの基礎になりうることは間違いな いであろう。

\section{V おわりに}

Lowry モデル (Lowry, 1964) に起源を発する 都市モデル研究の近年の動向は, 細分化 Disaggregation, 動態化 Dynamics, 統合 Integration の 3つを主流としている (Batty，1981). そして，こ れらの展開の基盤をなしてきたものは, 単純な Lowry モデル・メカニズムであった，確かにこ

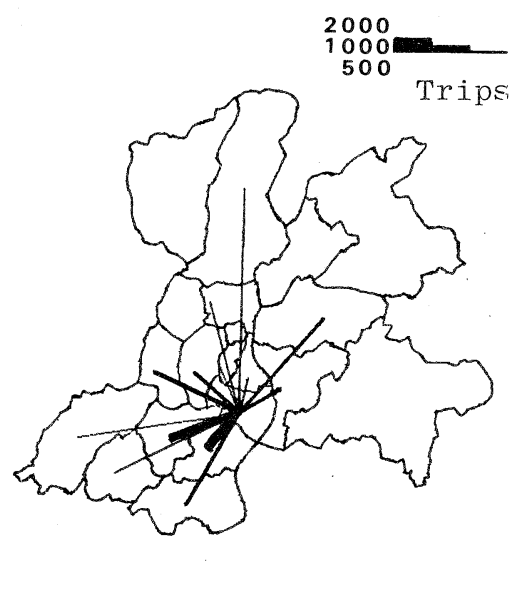

b) Predicted

第 9 図 モデル2-c の適用結果（トヨ夕・山之手〔11〕への通勤流(製造業)）

Fig. 9 In-flow patterns of journey-to-work of manufacturing to Toyota-Yamanote [11] predicted by model $2-\mathrm{c}$ 
のモデル・メカニズムは都市内部にみられる活動間 の本質的な相互作用のいくつかを捉え，他の多くの モデルの基礎となるアイデアを提供してきた(Wilson and Bennett, 1985, p. 329). 他方で, その非 現実的な仮定や操作上の問題が，より適切なモデル ・メカニズムの再考を促してきたのも事実である.

Lowry モデルを構成する基本モデルの 1 つである 活動の配分のサブ・モデルに関しては, 単純な重力 モデルから Wilson (1970) のエントロピー最大化 型空間的相互作用モデルへと置き換えられ, 最近で はさらにWilson モデルを包損する競合着地モデル の導入が図られてきた（知野，1986）。これに対し て，もう 1 つの基本モデルである活動の発生サブ・ モデルに関しては、これまで一貫して経済基盤理論 に基づく乗数モデルが適用されてきた. しかし, 経 済基盤乗数メカニズムに含まれる, 基幹部門の活動 水準によってのみ人口と雇用者の水準が決定すると いう非現実的な仮定や, 基幹産業之非基幹産業の定 義・分類の問題は無視しえないものであった（ $\mathrm{Sa}$ yer, 1976 ; Webber, 1984).

こうした問題に対して, 本稿では豊田市を対象に Macgill（1977）の枠組にしたがって, 経済基盤乗 数モデルにかわり, 地域投入係数の推定に準調査法 の 1 つであるRAS 法を援用した地域産業連関分析 をLowry モデル・メカニズムに取り込むことに よって, Lowry モデル族の一般化を試みた。結果 は以下のように要約される。

1) 非基幹部門間の相互作用を認めず，外生的に 与えられる基幹部門の水準によってのみ世帯部門之 非基幹部門の水準が決定されるという仮定において は（モデルaに対応），非基幹部門の相互作用を認 めた場合に比べ (モデル bに対応)，人口および非 基幹産業雇用者数の推定値が過小評価されているこ とが明らかになった。このことは, 従来の Lowry モデル・メカニズムでは，実際にみられる部門間な らびに地区間の相互作用のうちごく限られたものだ
けが扱われていることを示唆するものである。

2）地域間投入一産出モデルに対応する非集計的 空間レベルでの一般化の結果からは，基幹部門を外 生部門としたモデルの寒行において(モデル2-a， b), 豊田自動車の工場立地地区での過大評価，北 部や東部の周辺地域での過小評価といった，推定さ れた活動水準の空間的分布の差異がみられた。また， 買物流に関しても，南部の工場立地地区において全 般的な過大評価がみられた。そしてさらに，基幹部 門を内生化させ, 最終需要を外生部門としたモデル の実行からは (モデル2-c), 総雇用者数の絶対量 の少ない非基幹部門を除き，人口や基幹部門産業で は極めて良好な適合結果がえられた。また，流動現 象，とりわけ通勤流については概ね良好な結果がえ られた。

これらの結果は, Lowry モデル族の活動の発生 サブ・モデルが依拠する経済基盤メカ二ズムの限界 を明示する一方, 経済基盤乗数モデルにかわる地域 産業連関分析による一般化の妥当性を支持し ${ }^{10)}$, 基 幹部門を内生化させたより包括的な枠組による Lowry モデル族の定式化の可能性を示唆するもの よいえる。

本稿を作成するに当たって，日頃からご指導たまわって いる杉浦芳夫先生をはじめとする東京都立大学の都市・人 文系の諸先生, 諸先輩に感謝いたします。なお，本稿は， 1987 年 4 月の理論・計量地理学研究委員会の口頭発表に 加筆・修正を加えたものであり，その計算に当たっては， 東京都立大学電算機センターを利用した.

(投稿 1987 年 6 月 13 日) (受理 1987 年 10 月 3 日)

\section{注}

1）ストラクチャー・プランとは, 1960 年以降の英国に おける，地方行政区域 County を単位とした土地利用 の戦略的計画である。その計画策定システムは，1968 年の都市農村計画法によって制定されたとされている (戸田, 1984 b).

2）活動の配分サブ・モデルである空間的相互作用モデル をめぐる問題点に関しては, Sayer (1976, pp. 202 217)，杉浦（1986, pp. 178～181）を参照されたい.

3）地域産業連関分析については, 地理学において西脇 
（1975）の奏証研究があるが，そのモデル構造に関して は, Isard(1960, pp. 309〜374), Morrison and Smith (1977), Hewing (1985), 宮沢 (1975), 通商産業大臣. 官房調查統計部 (1967) を参照されたい.

4） RAS 法の呼称は，最初にこの方法を適用した研究者 がその計算過程で用いた，行列やベクトル（投入係数行 列，総投人および総産出ベクトル）の表記に由来するも のである、この方法は, Biproportional methodとも 呼ばれる。

5）本稿では対象地域を1つのシステムとみなすものを集 計的空間レベルとし，地域をいくつかの単位地区に細分 化したものを非集計的空間レベルと呼んでいる。

6) 経済基盤乗数メ力二ズムを始め, Lowry モデルの詳 細は, Batty (1976, pp. 24〜32, 55〜70), 高阪(1977), 矢野 (1986) を参照されたい.

7）生産的基準は当該産業による生産物が商品か無形の サービスかによって，立地的基準は当該産業が人口に対 して立地指向的か否かによって，機能的基準は当該産業 が直接地域経済に関連するか否かによって，それぞれ産 業を分類する基準である.

8）Lowry モデル族と地域産業連関分析の類似点に関し ては、Emmi (1983) が, Lowry モデルにおける雇用 者数と投入一産出モデルにおける賃金との関係を理論的 に扱っている。

9）本章の説明は，基本的に, Macgill(1977)とWebber (1984, pp, 98〜105) のものに準じている.

10）しかし，地域産業連関自身がもつ問題点についても留 意しておく必要があろう (Webber, 1984, p. 105)。 ま ず第 1 に，投入一産出モデルは線形モデルであるため, 規模の経済のような效果は考慮されえない, さらに, 地 域間投入一産出モデルで用いられた地域間投入係数では, 各部門の生産技術は空間的に差異がなく，雇用賃金さら に消費パターンに関しても空間的に一定であると仮定さ れている.こうした非現実的な仮定をいかに克服するか は今後の課題であるといえよう。

\section{文献}

愛知県企画部統計課 (1985): 『昭和 55 年 愛知の産業連関 表』愛知県企画部統計課, 302 ページ。

高阪宏行 (1977) : 経済基盤理論と都市モデル。人文地理 学研究， 1, 73 86.

杉浦芳夫 (1986): 空間的相互作用モデルの近年の展開 一重力モデルからエントロピー最大化型モデルへ—。 野上道男・杉浦芳夫共著:『パソコンによる数理地理学 演習』古今書院, 137 185.

通商産業大臣官房調査統計部編 (1967)：『昭和 35 年地域 間産業連関表による日本経済の地域連関分析』日本経済 新聞社, 357 ページ.

戸田常一（1984a）：土地利用モデルの適用と課題——米 国と英国におけるモデル開発を中心として一一. 土木学 会編：『都市の土地利用モデル』土木学会シンポジウム，
土木学会, $17 \sim 35$.

戸田常一 (1984 b) : 英国における戦略的計画之計画手法 について. 土木計画学研究講演集, 6, 9 16.

豐田市 (1984) : 『昭和 58 年版豊田市統計書』豊田市, 365 ページ.

西脇保幸 (1975)：人口増加による土地利用の変化一一浦 安町地域産業連関表を用いて一一. 地理評, $48,27 \sim 42$ 。 フット著, 青山吉隆・戸田常一・阿部宏史・近藤光男共訳 (1984): 『都市モデル—手法と応用』丸善, 207 ペシ. Foot, D. (1981) : Operational Urban Models : An introduction. Methuen, London, $231 \mathrm{p}$.

宮沢健一編 (1975): 『産業連関分析入門』（日経文庫, 経 済入門シリーズ)，日本経済新聞社，197ページ。

知野桂司 (1986) : 修正 Lowry モデルによる豊田市域の 都市内部システムの分析. 地理評, 59 (Ser. A)，523 $\sim 546$.

Bacharach, M. (1970): Biproportional Matrices and Input-Output Change. Cambridge Univ. Press, Cambridge, $170 \mathrm{p}$.

Batty, M. (1972) : Recent developments in land use modelling : a review of British research. Urban Studies, 9, 151 177.

Batty, M. (1976) : Urban Modelling : Algorithms, calibrations, predictions. Cambridge Univ. Press, Cambridge, $381 \mathrm{p}$.

Batty, M. (1978) : Paradoxes of Science in Public Policy: The baffling case of land use models. Geographical Papers, No. 69, Dept. of Geogr., Univ. of Reading, Reading, $34 \mathrm{p}$.

Batty, M. (1981) : Urban models. Wrigley, N. and Bennett, R. J. eds. : Quantitative Geography: A British view. Routledge and Kegan Paul, London, 181 191.

Batty, M. and Mackie, S. (1972): The calibration of gravity, entropy and related models of spatial interaction. Environ. Plann., 4, 206 233.

Bertuglia, C. S., Leonardi, G., Occelli, S., Rabino, G. A., Tadei, R. and Wilson, A. G. (1987): Urban System : Contemporary approaches to modelling. Croom Helm, London, $677 \mathrm{p}$.

Broadbent, T. A. (1973): Activity analysis of spatialallocation models. Environ. Plann., 5, 673 691.

Czamanski, S. and Malizia, E. E. (1969): Applicability and limitations in the use of national inputoutput tables for regional studies. Pap. Proc. Reg. Sci. Assoc., 23, 65 77.

Echenique, M., Crowther, D. and Lindsay, W. (1969): A spatial model of urban stock and activity. Reg. Stud., 3, 281 312.

Emmi, P. C. (1983): On the duality of employment and wages in the Garin-Lowry model. Environ. Plann. A, 15, 841 846. 
Foot, D. , Piasentin, U. and Costa, P. (1978): Urban Models II : A model of Venice. Geographical Papers, No. 66, Dept. of Geogr., Univ. of Reading, Reading, $44 \mathrm{p}$.

Garin, R. A. (1966) : A matrix formulation of the Lowry model for intrametropolitan activity location. J. Am. Inst. Plann., 32, 361 364.

Gordon, P. and Ledent, J. (1980): Modelling the dynamics of a system of metropolitan areas : a demoeconomic approach. Environ. Plann. A, 12, $125 \sim 133$.

Goldner, W. (1971) : The Lowry model heritage. J. Am. Inst. Plann., 37, 100 110.

Hewing, G. J. D. (1971) : Regional input-output models in the U.K. : some problems and prospects for the use of nonsurvey techniques. Reg. Stud., 5 , $11 \sim 22$.

Hewing, G. J. D. (1985) : Regional Input-Output Analysis. Scientific Geography Series, Vol. 6, Sage Publication, Beverly Hills, 96 p.

Isard, W. (1960): Methods of Regional Analysis. MIT Press, Cambridge, MA, 784 p. アイザード著, 笹田友三郎訳 (1969): 『地域分析の方法一一地域科学入 門——』朝倉書店, 324 ページ。

Lee, D. B. (1973) : Requiem for large scale models, J. Am. lnst. Plann., 39, 163 178.

Lowry, I. S. (1964) : A Model of Metropolis. RM4035-RC, Rand Corporation, Santa Monica, California, $136 \mathrm{p}$.

Macgill, S. M. (1977) : The Lowry model as an input-output model and its extension to incorpolate full inter-sectoral relations, Reg. Stud., 11, 337 354.

Malizia, E. and Bond, D. L. (1974): Empirical tests of the RAS Method of interindustry coefficient adjustment. J. Reg. Sci., 14, 355 366.

Massey, D. B. (1973): The basic-service categori- sation in planning. Reg. Stud, , 7, 1 15.

McMenamin, D. C. and Haring, J. E. (1974) : An appraisal of nonsurvey techniques for estimating regional input-output models. J. Reg. Sci., 14, $191 \sim 205$.

Morrison, W. I. and Smith, P. (1974) : Nonsurvey input-output techniques at the small area level: an evaluation. J. Reg. Sci, 14, 1 14.

Morrison, W. I. and Smith, P. (1977): Input-output methods in urban and regional planning : a practical guide. Prog. Plann., 7, 59 151.

Romanoff, E. (1974): The economic base model : a very special case of input-output analysis. J. Reg. Sci., 14, 121 129.

Round, J. I. (1983) : Nonsurvey techniques : a critical review of the theory and the evidence. International Reg. Sci. Rev., 8, 189 212.

Sayer, R. A. (1976): A critique of urban modelling. Prog. Plann., 6, 187 254.

Schaffer, W. A. and Chu, K. (1969): Nonsurvey techniques for constructing regional interindustry models. Pap. Proc. Reg. Sci. Assoc., 23, 83 101.

Schinnar, A. P. (1978) : Invariant distributional regularities of nonbasic spatial activity allocations: the Garin-Lowry model revisited. Environ. Plann. A, 10, 327 336 .

Webber, M. J. (1984) : Explanation, Prediction, and Planning: The Lowry model. Pion, London, $214 \mathrm{p}$. Wilson, A. G. (1970) : Entropy in Urban and Regional Modelling. Pion, London, $166 \mathrm{p}$.

Wilson, A. G. and Bennett, R. J. (1985): Mathematical Methods in Human Geography and Planning. John Wiley, Chichester, $411 \mathrm{p}$.

Yano, K. (1987): An extended Berry's field theoretic approach to intra-urban system in the Toyota planning region. Geogr. Repts. Tokyo Metropol. Univ., 22, 169 187. 


\section{THE GENERALIZED LOWRY MODEL AS AN INPUT-OUTPUT MODEL FOR AN URBAN SYSTEM OF TOYOTA CITY}

\section{Keiji YANO*}

The urban system model is derived from Lowry's (1964) classical model of the metroplis. The Lowry model is a model for allocating population and non-basic employment spatially from a given basic employment input, and is based on two principles of spatial interaction and urban economic base. The Lowry model mechanism offers a basis from which many other models can be formed by successfully capturing aspects of essential interdependencies among activities within a city.

Recently the focal points of urban modelling research are disaggregation, dynamics and integration. These advances have been fundamentally based on the classical Lowry model mechanism. Unsubstantiated assumptions and technical problems with the mechanism, however, have stimulated development of more adequate models and theories of the complex behavior of the urban system. The spatial interaction model, allocating urban activities spatially, has been enlarged and sophisticated through the entropy-maximizing methodology introduced by Wilson (1970).

Additionally, Fotheringham's competing destinations model has been incorporated into the Lowry type model (Yano, 1986). While the economic base model generating urban activities has been quite widely applied without remarkable modification so far, over-simplified assumptions concerning the mechanism and problems of definition and categorization of basic and non-basic industries cannot be ignored (Sayer, 1976 ; Webber, 1984).

In order to avoid conceptual and empirical difficulties associated with the economic base mechanism, Macgill (1977) attempted a generalization of Lowry's model by substituting the input-output model for the economic base model (Figures 1 and 2). The greatest advantage of this adaptation is the incorporation of full inter-activity relations, in contrast to Lowry's restriction to three all-embracing activity types, namely, basic, non-basic and household, with only partial interaction between them. In addition, while the original Lowry model assumes that basic employees are given a priori in each zone, Macgill's framework renders this assumption unnecessary by making basic sectors endogenous. Therefore, it is possible to derive the model given final demand in the conventional input-output sense as well as given basic employment.

The purpose of this paper is to evaluate the generalized Lowry model as an input-output model proposed by Macgill (1977) through its application to Toyota City (Figure 3). The main difficulty with operationalization is the virtual unavailability of a set of intersectoral input-output coefficients for the city being studied. Thus, in estimating the input-output coefficients for Toyota City, the RAS or biproportinal technique, which is one of the partial survey techniques, is used to adjust the coefficients for Aichi prefecture.

The Lowry model mechanism in terms of spatially aggregated and disaggregated input-output models is presented. These models are in accordance with Macgill (1977) and Webber (1984, 
pp. 98-105). The former corresponds with an intra-regional input-output model and the latter with an inter-regional input-output model. Three models are performed in spatially-aggregated (Model I) and disaggregated (Model II) representations : Model "a" assumes that basic sectors are exogenous and that there are no intersectoral relations between non-basic sectors, as is faithful to the Lowry model mechanism ; Model " $b$ " incorporates inter-activity relations between non-basic sectors into Model "a"; and Model "c" assumes that basic sectors are endogenous and final demand estimated is exogenous, and that full inter-activity relations are incorporated. The outline of these models is shown in Figure 4.

The results of the calibrations of these models are summarized as follows :

1) In Models I-a and II-a, which are based on the Lowry model, the levels of population and employment of non-basic industries are undervalued as compared with Models I-b and II-b which do incorporate those relations ignored in the Lowry model (Table 1). This suggests that the existing Lowry model mechanism only takes rather restricted inter-activity relations into consideration.

2) In Models II-a and II-b, that is, the spatially-disaggregated Lowry model corresponding to the inter-regional input-output model where basic employment is exogeneously given, zonal populations are predicted with poor goodness-of-fit, and zonal employees of non-basic industries are with $r=0.6386 \sim 0.9302$ (Table 3). In terms of spatial distribution, there are positive residuals in the areas where main factories are located and negative residuals in the northern and eastern areas (Figure 5). For journey-to-shop, overvaluation is apparent in the southern areas (Figure 6).

3) In Model II-c, zonal populations and basic industry employment are estimated with very adequate goodness-of-fit, while this model proves not to be so predictive of employment of non-basic industries with few employees (Table 4 and Figure 7). Spatial interaction, especially journey-to-work, is simulated fairly well (Figures 8 and 9).

These results reveal the weakness of the economic base mechanism which Lowry used to construct a representation of production economics of urban areas, and support the appropriateness of the Lowry model as generalized within an input-output framework. Moreover, this framework provides a basis for more comprehensive urban models.

(Key words: Lowry model, Regional input-output model, RAS method, Toyota City, urban system) 